\title{
Non-Ideality in Solvent Extraction Systems: PNNL FY 2014 Status Report
}

Fuel Cycle Research \& Development

Prepared for U.S. Department of Energy Separations Campaign TG Levitskaia, SD Chatterjee, NK Pence Pacific Northwest National Laboratory

September 2014 FCRD-SWF-2014-000240

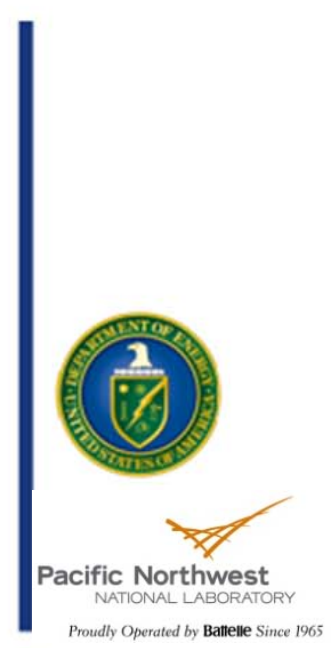




\section{DISCLAIMER}

This information was prepared as an account of work sponsored by an agency of the U.S. Government. Neither the U.S. Government nor any agency thereof, nor any of their employees, makes any warranty, expressed or implied, or assumes any legal liability or responsibility for the accuracy, completeness, or usefulness, of any information, apparatus, product, or process disclosed, or represents that its use would not infringe privately owned rights. References herein to any specific commercial product, process, or service by trade name, trade mark, manufacturer, or otherwise, does not necessarily constitute or imply its endorsement, recommendation, or favoring by the U.S. Government or any agency thereof. The views and opinions of authors expressed herein do not necessarily state or reflect those of the U.S. Government or any agency thereof. 


\section{SUMMARY}

The overall objective of this project is to develop predictive modeling capabilities for advanced fuel cycle separation processes by gaining a fundamental quantitative understanding of non-ideality effects and speciation in relevant aqueous and organic solutions. Aqueous solutions containing actinides and lanthanides encountered during nuclear fuel reprocessing have high ionic strength and do not behave as ideal solutions. Activity coefficients must be calculated to take into account the deviation from ideality and predict their behavior.

In FY 2012-2013, a convenient method for determining activity effects in aqueous electrolyte solutions was developed. Our initial experiments demonstrated that water activity and osmotic coefficients of the electrolyte solutions can be accurately measured by the combination of two techniques, a Water Activity Meter and Vapor Pressure Osmometry (VPO). The water activity measurements have been conducted for binary lanthanide solutions in wide concentration range for all lanthanides (La-Lu with the exception of Pm). The osmotic coefficients and Pitzer parameters for each binary system were obtained by the least squares fitting of the water activity data. However, application of Pitzer model for the quantitative evaluation of the activity effects in the multicomponent mixtures is difficult due to the large number of the required interaction parameters.

In FY 2014, the applicability of the Bromley model for the determination of the $\mathrm{Ln}\left(\mathrm{NO}_{3}\right)_{3}$ activity coefficients was evaluated. The new Bromley parameters for the binary $\operatorname{Ln}\left(\mathrm{NO}_{3}\right)_{3}$ electrolytes were obtained based on the available literature and our experimental data. This allowed for the accurate prediction of the $\mathrm{Ln}\left(\mathrm{NO}_{3}\right)_{3}$ activity coefficients for the binary $\mathrm{Ln}\left(\mathrm{NO}_{3}\right)_{3}$ electrolytes. This model was then successfully implemented for the determination of the $\mathrm{Ln}\left(\mathrm{NO}_{3}\right)_{3}$ activity coefficients in the ternary $\mathrm{Nd}\left(\mathrm{NO}_{3}\right)_{3} / \mathrm{HNO}_{3} / \mathrm{H}_{2} \mathrm{O}, \mathrm{Eu}\left(\mathrm{NO}_{3}\right)_{3} / \mathrm{HNO}_{3} / \mathrm{H}_{2} \mathrm{O}$, and $\mathrm{Eu}\left(\mathrm{NO}_{3}\right)_{3} / \mathrm{NaNO}_{3} / \mathrm{H}_{2} \mathrm{O}$ systems. The main achievement of this work is the verified pathway for the estimation of the activity coefficients in the multicomponent aqueous electrolyte systems. The accurate Bromley electrolytes contributions obtained in this work for the entire series of lanthanide(III) nitrates (except Pm) can be applied for predicting activity coefficients and non-ideality effects for multi-component systems containing these species. This work also provides the proof-of-principle of extending the model to more complex multicomponent systems. Moreover, this approach can also be applied to actinide-containing electrolyte systems, for determination of the activity coefficients in concentrated radioactive solutions. 


\section{CONTENTS}

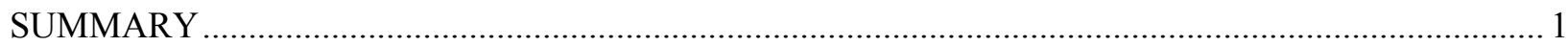

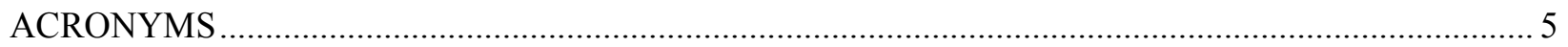

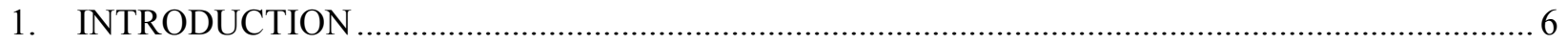

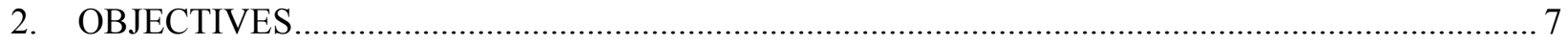

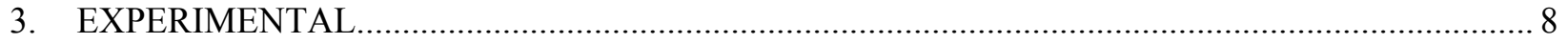

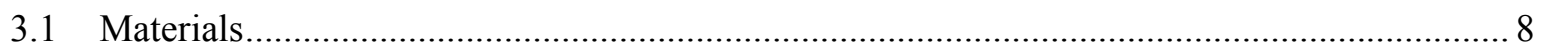

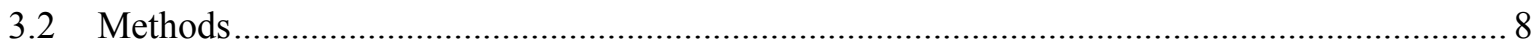

3.3 Water Activity Data Treatment to Determine Activity Coefficients and Bromley

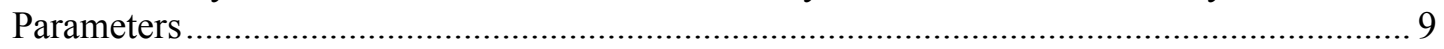

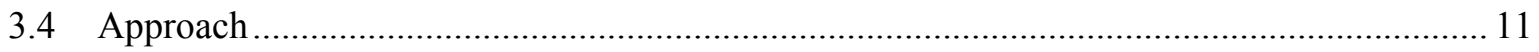

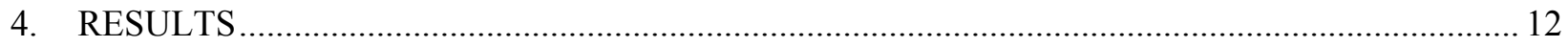

4.1 Bromley parameters for binary $\mathrm{Ln}\left(\mathrm{NO}_{3}\right)_{3} / \mathrm{H}_{2} \mathrm{O}$ solutions $(3: 1$ electrolytes) ........................ 12

4.2 Bromley parameters for binary $\mathrm{HNO}_{3} / \mathrm{H}_{2} \mathrm{O}$ and $\mathrm{NaNO}_{3} / \mathrm{H}_{2} \mathrm{O}$ solutions $(1: 1$

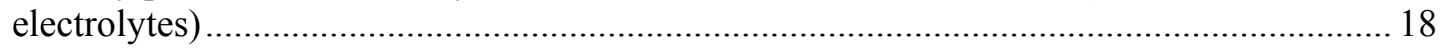

4.3 Water Activity Measurements and Activity Coefficients for the Ternary

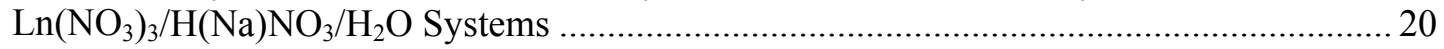

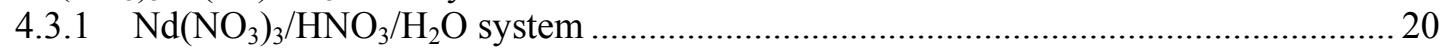

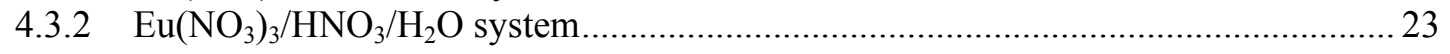

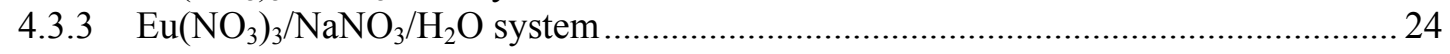

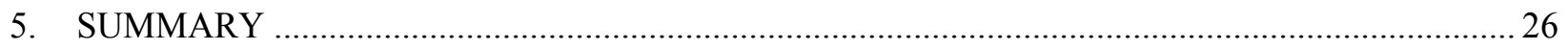

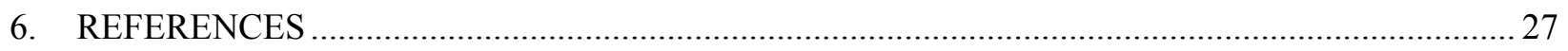

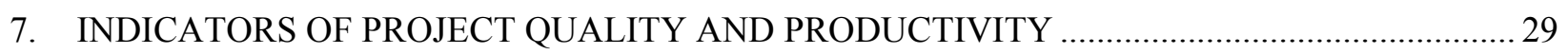

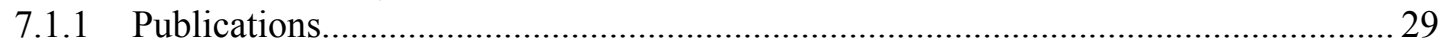

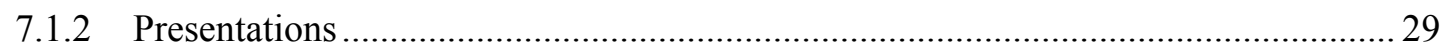

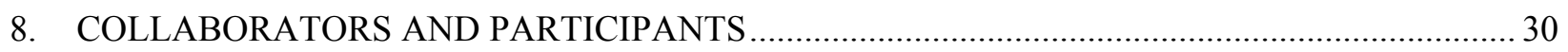




\section{FIGURES}

Figure 4.1. Comparison of the experimental (symbols) and calculated by the original (blue trace) or improved (black trace) Bromley's model activity coefficients for the lighter binary $\operatorname{Ln}\left(\mathrm{NO}_{3}\right)_{3}$ electrolytes. The literature data are taken from Spedding et al., 1976; Rard, et al., 1977; Rard and Spedding 1979; Rard et al., 1981.

Figure 4.2. Comparison of the experimental (symbols) and calculated by the improved (black trace) Bromley's model activity coefficients for the heavier binary $\mathrm{Ln}\left(\mathrm{NO}_{3}\right)_{3}$ electrolytes. The literature data are taken from Spedding et al., 1976; Rard, et al., 1977; Rard and Spedding 1979; Rard et al., 1981.

Figure 4.3. Comparison of the experimental (symbols) and calculated by the improved (black trace) Bromley's model activity coefficients for the binary $\mathrm{Ce}\left(\mathrm{NO}_{3}\right)_{3}$ electrolyte.

Figure 4.4. A plot of BLnNO33 versus the ionic radii. The $\mathrm{Ce}^{3+}$ data point is marked with a blue circle to differentiate it from the rest of the lanthanides as its activity coefficient was obtained based solely on our data using Pitzer treatment.

Figure 4.5. Comparison of the $\mathrm{HNO}_{3}$ activity coefficients calculated using Bromley's model $(\mathrm{BHNO} 3=$ 0.0776) with the literature (Charrin et al., 1999) and our experimental values.

Figure 4.6. Comparison of the $\mathrm{NaNO}_{3}$ activity coefficients calculated using Bromley's model (BNaNO3 $=-0.0128)$ with the literature (Marcos-Aroyo et al., 1996) and our experimental data.

Figure 4.7. Plot of the water activity versus the ionic strength for $\mathrm{Nd}\left(\mathrm{NO}_{3}\right)_{3} / \mathrm{HNO}_{3} / \mathrm{H}_{2} \mathrm{O}$ ternary system 21

Figure 4.8. Comparison of water activities for the $\mathrm{Nd}\left(\mathrm{NO}_{3}\right)_{3} / \mathrm{HNO}_{3} / \mathrm{H}_{2} \mathrm{O}$ ternary system with the $\mathrm{Nd}\left(\mathrm{NO}_{3}\right)_{3} / \mathrm{H}_{2} \mathrm{O}$ binary system.

Figure 4.9. Plot of activity coefficients versus the ionic strength for the $\mathrm{Nd}\left(\mathrm{NO}_{3}\right)_{3} / \mathrm{HNO}_{3} / \mathrm{H}_{2} \mathrm{O}$ ternary system......

Figure 4.10. Comparison of the $\mathrm{Nd}\left(\mathrm{NO}_{3}\right)_{3}$ activity coefficients for $\mathrm{Nd}\left(\mathrm{NO}_{3}\right)_{3} / \mathrm{HNO}_{3} / \mathrm{H}_{2} \mathrm{O}$ ternary and $\mathrm{Nd}\left(\mathrm{NO}_{3}\right)_{3} / \mathrm{H}_{2} \mathrm{O}$ binary systems.

Figure 4.11. Comparison of the water activity in the $\mathrm{Eu}\left(\mathrm{NO}_{3}\right)_{3} / \mathrm{HNO}_{3} / \mathrm{H}_{2} \mathrm{O}$ ternary and $\mathrm{Eu}\left(\mathrm{NO}_{3}\right)_{3} / \mathrm{H}_{2} \mathrm{O}$ binary systems.

Figure 4.12. Comparison of the $\mathrm{Eu}\left(\mathrm{NO}_{3}\right)_{3}$ activity coefficients in the $\mathrm{Eu}\left(\mathrm{NO}_{3}\right)_{3} / \mathrm{HNO}_{3} / \mathrm{H}_{2} \mathrm{O}$ ternary and $\mathrm{Eu}\left(\mathrm{NO}_{3}\right)_{3} / \mathrm{H}_{2} \mathrm{O}$ binary systems.

Figure 4.13. Comparison of the water activity in the $\mathrm{Eu}\left(\mathrm{NO}_{3}\right)_{3} / \mathrm{NaNO}_{3} / \mathrm{H}_{2} \mathrm{O}$ ternary and $\mathrm{Eu}\left(\mathrm{NO}_{3}\right)_{3} / \mathrm{H}_{2} \mathrm{O}$ binary systems.

Figure 4.14. Comparison of the $\mathrm{Eu}\left(\mathrm{NO}_{3}\right)_{3}$ activity coefficients in the $\mathrm{Eu}\left(\mathrm{NO}_{3}\right)_{3} / \mathrm{NaNO}_{3} / \mathrm{H}_{2} \mathrm{O}$ ternary and $\mathrm{Eu}\left(\mathrm{NO}_{3}\right)_{3} / \mathrm{H}_{2} \mathrm{O}$ binary systems. 


\section{TABLES}

Table 4.1. Tabulation of the individual BLn3 + and $\delta \operatorname{Ln} 3+$ parameters reported by Bromley (1973) for trivalent lanthanides and the corresponding electrolyte BLnN033contributions calculated using equation 18

Table 4.2. Tabulation of the electrolyte BLnNO33contributions calculated by fitting Bromley's model (equation 11) to activity coefficient data obtained from a combination of the literature and our data.

Table 4.3. Pitzer parameters for the $\mathrm{Ce}\left(\mathrm{NO}_{3}\right)_{3}$ binary electrolyte.

Table 4.4. Water activity and $\mathrm{Nd}\left(\mathrm{NO}_{3}\right)_{3}$ activity coefficients for the $\mathrm{Nd}\left(\mathrm{NO}_{3}\right)_{3} / \mathrm{HNO}_{3} / \mathrm{H}_{2} \mathrm{O}$ ternary system. The activity coefficients $\gamma_{ \pm}$were calculated using the Bromley's model by equation 12. ...... 20

Table 4.5. Water activity and $\mathrm{Eu}\left(\mathrm{NO}_{3}\right)_{3}$ activity coefficients for the $\mathrm{Eu}\left(\mathrm{NO}_{3}\right)_{3} / \mathrm{HNO}_{3} / \mathrm{H}_{2} \mathrm{O}$ ternary system. The activity coefficients $\gamma_{ \pm}$were calculated using the Bromley's model by equation 12 .......23

Table 4.6. Water activity and $\mathrm{Eu}\left(\mathrm{NO}_{3}\right)_{3}$ activity coefficients for the $\mathrm{Eu}\left(\mathrm{NO}_{3}\right)_{3} / \mathrm{NaNO}_{3} / \mathrm{H}_{2} \mathrm{O}$ ternary system. The activity coefficients $\gamma_{ \pm}$were calculated using the Bromley's model by equation 12 
Non-Ideality in Solvent Extraction Systems: PNNL FY 2014 Status Report

September 2014

\section{ACRONYMS}

FY fiscal year

Ln lanthanide

PNNL Pacific Northwest National Laboratory

VPO Vapor Pressure Osmometry 


\section{INTRODUCTION}

The overall project objective is to develop predictive modeling capabilities based on solution thermodynamics to support nuclear fuel research and development needs. Successful design of liquidliquid extraction processes for new fuel cycle concepts, currently considered by the advanced aqueous reprocessing campaign, largely relies on the availability of such predictive capability. A major goal of the U.S. Department of Energy Office of Nuclear Energy is to increase utilization of the fuel resource and reduce the quantity of actinides that would be disposed in used fuel. To this end, design of a solvent extraction separation process that achieves an accurately controlled selective transport of the species of interest is of paramount importance.

In used nuclear fuel reprocessing, trivalent lanthanides are present at significant concentration levels among the nuclear fission products. The separation of the trivalent actinides from trivalent lanthanides is $\underline{a}$ desirable but challenging step in closing the nuclear fuel cycle. Streams generated during the reprocessing of the used nuclear fuel are complex concentrated solutions containing several electrolytes and cannot be assumed as ideal due to the interactions between the components. These solutions often contain nitric acid and nitrate salts of multivalent metal ions resulting in high ionic strength typically ranging from 3 to $10 \mathrm{~mol} \mathrm{~kg}^{-1}$ (Warin et al., 2009). Consequently the deviation from the thermodynamic ideality has to be taken into account to calculate the thermodynamic properties of solutions and predict their behavior.

To thoroughly model the equilibrium reactions and predict the behavior of solvent extraction systems, it is necessary to have means to calculate the activity coefficients or osmotic coefficients as a measure of the non-ideality for the key species in the aqueous electrolyte solutions. To date, only limited experimental data describing non-ideality effects of the aqueous solutions of lanthanide and actinide ions are available, which makes the development of predictive modeling challenging.

The classical isopiestic method is one of the most conventional methods for determining osmotic coefficients of electrolyte mixtures. It consists of placing samples of different solutions in separate open containers under isothermal conditions and allowing them to exchange solvent by vapor diffusion in a sealed chamber until thermodynamic equilibrium is reached. The method uses a standard with known osmotic coefficient, and the osmotic coefficient of the sample being analyzed can be calculated via equation 1:

$$
\phi=v^{*} m^{*} \phi^{*} / \sum_{j} v_{j} m_{j}
$$

where $\phi$ is the osmotic coefficient, $v$ is the stoichiometric number of ions in electrolyte sample $\mathrm{j}, *$ refers to the standard, and $\mathrm{m}$ is the molality. The advantage of the isopiestic method is that it gives a direct measure of osmotic coefficients. The main disadvantage of this method for testing of the used nuclear fuel solutions is that it is unable to analyze systems containing volatile species other than water, e. g., nitric acid. Additionally, the method requires rather long equilibration times and very accurate temperature control making it inapplicable for collecting large volumes of experimental data.

Our FY 2012-2013 experiments demonstrated that water activity and osmotic coefficients of the electrolyte solutions can be accurately measured by the combination of two techniques, a Water Activity Meter and Vapor Pressure Osmometry (VPO). In this method, one technique is based on measurement of vapor pressure of an aqueous electrolyte by a variable impedance hygrometer of a Water Activity Meter, which converts it to water activity. The osmotic coefficient can be calculated from the water activity by equation 2:

$$
\phi=\frac{-1000 \ln \left(a_{w}\right)}{v m_{A X} M_{H 2 O}}
$$


where $a_{\mathrm{w}}$ is the water activity, $\phi$ is the osmotic coefficient, $v$ is the stoichiometric number of ions in electrolyte sample $\mathrm{AX}, \mathrm{m}$ is the molality, and $M_{\mathrm{H} 2 \mathrm{O}}$ is the molecular weight of water. The VPO technique measures osmolality $m_{\text {osm }}$ which then is used to calculate osmotic coefficient by equation 3 :

$$
\phi=\frac{m_{o s m}}{1000 v m}
$$

In our previous report, we showed that the osmotic coefficient data obtained from VPO measurements at low concentration regimes can complement the results obtained from Water Activity measurements at high concentration regions to provide a reliable alternative to the isopiestic measurements for the assessment of the non-ideality effects in the aqueous electrolyte solutions (Levitskaia et al., 2013). Our results showed excellent agreement of experimental water activity and osmotic coefficient data with literature isopiestic data for binary 1:1 alkali chloride and 3:1 lanthanide nitrate systems. The water activity measurements have been conducted for binary lanthanide solutions in wide concentration range for all lanthanide nitrates ( $\mathrm{La}-\mathrm{Lu}$ with the exception of $\mathrm{Pm}$ ) and used for the determination of the osmotic coefficients and Pitzer parameters for each binary system.

In this work our aim is to extend our measurements to multicomponent systems and find a reliable method to determine activity coefficients of multicomponent systems. Two models were developed for concentrated solutions containing multicomponent electrolytes: one by Bromley (Bromley, 1973) and one by Pitzer (Pitzer, 1991). Both methods take into account short and long-range interactions: the Bromley method is an empirical approach while the Pitzer method is based on a physico-chemical approach based on statistical mechanical calculations. In our previous work on the binary 1:1 alkali chloride and 3:1 lanthanide nitrate systems, the reliability of our thermodynamic data provided us the confidence to build a thermodynamic model for the binary electrolyte systems using Pitzer equations, which yielded accurate Pitzer parameters. However, extension of the Pitzer model to multicomponent system requires many parameters to be adjusted from experimental data, necessitating heavy experimentation. On the other hand, as a first approximation, Bromley's model offers a good compromise between accuracy and ease of application. In this work, we aim to extend our work to build an alternate model for binary 3:1 lanthanide nitrates using Bromley equations based on the our and literature data. Subsequently, the binary Bromley model is extended to ternary systems.

\section{OBJECTIVES}

The overall objective of this work is to gain systematic information on non-ideality effects of the lanthanide and actinide ions in the electrolyte solutions applicable to the quantitative prediction of their transport behavior in solvent extraction and other aqueous separation schemes.

The specific objectives of the FY 2014 work are two-fold:

(a) To build an accurate model for predicting the non-ideality behavior of binary multicomponent mixtures using accurate thermodynamic data for the binary systems including 3:1 lanthanide nitrates and 1:1 $\mathrm{HNO}_{3} / \mathrm{NaNO}_{3}$ and systems using Bromley equations. The objective is to obtain improved Bromley constants which can be used for more complex multicomponent systems.

(b) Apply the obtained Bromley binary parameter to predict the activity coefficients on lanthanide nitrates in the ternary systems. 


\section{EXPERIMENTAL}

\subsection{Materials}

The inorganic salts used to prepare aqueous electrolyte solutions were $\mathrm{NaCl}, 99.99 \% ; \mathrm{Ce}\left(\mathrm{NO}_{3}\right)_{3} \cdot 6 \mathrm{H}_{2} \mathrm{O}$; 99.999\%; $\mathrm{La}\left(\mathrm{NO}_{3}\right)_{3} \cdot 6 \mathrm{H}_{2} \mathrm{O} ; 99.999 \% ; \mathrm{Nd}\left(\mathrm{NO}_{3}\right)_{3} \cdot 6 \mathrm{H}_{2} \mathrm{O}, 99.9 \% ; \operatorname{Pr}\left(\mathrm{NO}_{3}\right)_{3} \cdot 6 \mathrm{H}_{2} \mathrm{O}, 99.9 \% ; \mathrm{Eu}\left(\mathrm{NO}_{3}\right)_{3} \cdot 6 \mathrm{H}_{2} \mathrm{O}$, 99.9\%; $\mathrm{Gd}\left(\mathrm{NO}_{3}\right)_{3} \cdot 6 \mathrm{H}_{2} \mathrm{O}, 99.9 \% ; \mathrm{Ho}\left(\mathrm{NO}_{3}\right)_{3} \cdot 5 \mathrm{H}_{2} \mathrm{O}, 99.9 \% ; \mathrm{Dy}\left(\mathrm{NO}_{3}\right)_{3} \cdot \mathrm{xH}_{2} \mathrm{O}, 99.9 \% ; \mathrm{Er}\left(\mathrm{NO}_{3}\right)_{3} \cdot 5 \mathrm{H}_{2} \mathrm{O}$, 99.9\%; $\mathrm{Tb}\left(\mathrm{NO}_{3}\right)_{3} \cdot 5 \mathrm{H}_{2} \mathrm{O}, 99.9 \% ; \mathrm{Tm}\left(\mathrm{NO}_{3}\right)_{3} \cdot 5 \mathrm{H}_{2} \mathrm{O}, 99.9 \% ; \mathrm{Lu}\left(\mathrm{NO}_{3}\right)_{3} \cdot 5 \mathrm{H}_{2} \mathrm{O}, 99.9 \% ; \mathrm{Sm}\left(\mathrm{NO}_{3}\right)_{3} \cdot 6 \mathrm{H}_{2} \mathrm{O}$, 99.9\% and $\mathrm{Yb}\left(\mathrm{NO}_{3}\right)_{3} \cdot 6 \mathrm{H}_{2} \mathrm{O}, 99.9 \%$ obtained from Sigma-Aldrich and $\operatorname{Pr}\left(\mathrm{NO}_{3}\right)_{3} \cdot 6 \mathrm{H}_{2} \mathrm{O}, 99.99 \%$ obtained from Alfa Aesar. Sodium chloride was dried at $120^{\circ} \mathrm{C}$ under dynamic vacuum. Other salts were used as received. Concentrated nitric acid ( $70 \%$ ACS reagent grade) was obtained from Sigma-Aldrich. The aqueous solutions were prepared using quartz pure water. A quartz double distillation system was used to purify the water used in these experiments (procedure can be found at http://www.avexports.net/waterdistiller-quartz.html.quartz-double-distillation-unit). The solutions were prepared by weighing the salts and the water, and the concentrations were recorded in molality. Density measurements were used to determine the salt concentrations of the stock solutions. Potentiometric titrations with standardized $\mathrm{NaOH}$ were used to determine nitric acid stock concentration. The stock solutions were then diluted with deionized water by mass to create a series of solutions that were analyzed by the water activity techniques described below.

\subsection{Methods}

Water activity $\left(a_{\mathrm{w}}\right)$ measurements were performed using AquaLab 4ETV Water Activity Meter (Novasina AG, Lachen Switzerland) consisting of a Lab Master controller unit coupled with three Lab Partners units. The Novasina instruments measure water activity with an accuracy of $0.003 a_{\mathrm{w}}$. The water activity meter was calibrated using six standards provided by Novasina, SAL-T consisting of saturated salts solutions of known humidities: $0.973 \pm 0.003,0.843 \pm 0.003,0.753 \pm 0.003,0.576 \pm 0.003,0.328 \pm 0.003$, and $0.113 \pm 0.003$. In addition, the quartz pure water was used as a standard with a water activity $a_{\mathrm{w}}=1$. All water activity measurements were performed at $25 \pm 0.1^{\circ} \mathrm{C}$ and each chamber was protected with the Novasina EVC-21 acid vapor filter. The sample is put in the measurement chamber and allowed to equilibrate at $25{ }^{\circ} \mathrm{C}$ for 30 minutes prior to each measurement. The free water present in the sample humidifies or dehumidifies the air volume inside the chamber until the partial pressure of water vapor saturation is zero. The instrument temperature and pressure changes inside the chamber are monitored via a computer interface. If these parameters remain stable over 1 to $2 \mathrm{hrs}$ (adjustable by the user), then the instrument converts that into $a_{\mathrm{w}}$.

The osmolality of binary electrolyte solutions with high water activity $\left(a_{\mathrm{w}}>0.97\right)$ was measured using a vapor pressure osmometer (VPO) Vapro 5520 (Wescor, Inc., Logan UT). All VPO measurements were performed in a temperature-controlled glove-box enclosure maintained at $25.0 \pm 0.2^{\circ} \mathrm{C}$. The instrument was calibrated using the manufacturer supplied osmolality calibration standards $\left(100,290,1000 \mathrm{mmol} \mathrm{kg}^{-}\right.$

${ }^{1} \mathrm{NaCl}$ in water). The osmolality of the solutions were used to calculate the osmotic coefficient as shown in equation 3.

Solution density was determined using a $10 \mathrm{~mL}$ pycnometer obtained from Thomas Glass. The temperature of the solution was determined immediately following weighing using a digital thermometer whose tip was immersed in the solution. 


\subsection{Water Activity Data Treatment to Determine Activity Coefficients and Bromley Parameters}

Values of the Bromley parameters for the binary electrolyte systems were determined by fitting experimentally measured activity coefficients either using Microsoft Excel platform or OriginPro 8 software (http://www.originlab.com).

To thoroughly model the equilibrium reactions and predict the behavior of solvent extraction systems, it is necessary to have means to calculate the activity coefficients as a measure of the non-ideality for the key species in the aqueous electrolyte solutions. The formalism for the calculation of a thermodynamic mean activity coefficient was originally proposed by Debye Hückel (Debye Hüickel, 1923) according to the equation 4:

$$
\begin{gathered}
\log \gamma_{ \pm}=-A_{c}\left|z_{+} z_{-}\right| \sqrt{I_{c}} \\
I_{c}=\frac{1}{2} \sum_{i} z_{i}^{2} C_{i}
\end{gathered}
$$

where $I_{\mathrm{c}}$ is the ionic strength in molarity scale, $z_{+} / z_{\text {. }}$ is the cation/anion charge, $C_{\mathrm{i}}$ the ion i molarity and $A_{\mathrm{c}}$ the Debye-Hückel constant expressed as:

$$
A_{c}=(2 \pi N)^{\frac{1}{2}} \frac{1}{\ln (10)\left(4 \pi \varepsilon_{0}\right)^{\frac{3}{2}}}\left(\frac{e^{2}}{\varepsilon k T}\right)^{3 / 2}
$$

Here $\varepsilon$ is the dielectric constant of the solvent, $N$ is the Avogadro number, $e$ the elementary charge, $\varepsilon_{0}$ the permittivity in free space, $k$ the Boltzmann constant and $T$ the temperature. However, the main problem with Debye-Hüickel model was that ions were assumed to be point charges in a continuous dielectric medium. Furthermore, the model was only applicable to low ionic strength solutions $\left(<0.001 \mathrm{~mol} \mathrm{~L}^{-1}\right)$ and therefore only took into account the long range interaction between ions of opposite charges, while the short range interactions that occur in concentrated solutions between ions were disregarded.

| The model was later amended (Debye Hückel, 1923) to equation 7 where ions were considered to be hard spheres instead of point charges. The diameter of the spheres are given by $\dot{a}$,

$$
\log \gamma_{ \pm, c}=-A_{c}\left|z_{+} z_{-}\right| \frac{\sqrt{I_{c}}}{1+B_{c} \dot{a} \sqrt{I_{c}}} \quad \quad \text { where } \quad B_{c}=\left(\frac{8 \pi N}{1000}\right)^{1 / 2} \frac{e}{\left(4 \pi \varepsilon_{0}\right)^{1 / 2}(\varepsilon k T)^{1 / 2}}
$$

However, it was still not applicable for solutions with ionic strength greater than $0.01 \mathrm{~mol} \mathrm{~L}^{-1}$.

Bromley later suggested a modified model (Bromley, 1973) for more concentrated solutions (up to ionic strength of $1 \mathrm{~mol} \mathrm{~L}^{-1}$ ) containing higher terms of ionic strength (equation 8 ). The constants $\beta_{m}, C, D \ldots$ are empirical and are not assigned any physical meaning. The main drawback of this method is that no distinction is made between ions, which have the same charge but of different chemical nature. Additionally, they cannot be applied for concentrated solution with ionic strength $>1 \mathrm{~mol} \mathrm{~L}^{-1}$, and cannot be applied to multicomponent systems.

$$
\log \gamma_{ \pm, m}=-A_{m}\left|z_{+} Z_{-}\right| \frac{\sqrt{I_{c}}}{1+B_{c} \dot{a} \sqrt{I_{c}}}+\beta_{m} I_{m}+C I_{m}^{2}+D I_{m}^{3}+\cdots
$$




$$
\begin{array}{r}
I_{m}=\frac{1}{2} \sum_{i} z_{i}^{2} m_{i} \\
A_{m}=A_{C}\left(\frac{\rho_{\mathrm{H}_{2} O} \mathrm{O}}{1000}\right)^{1 / 2}
\end{array}
$$

To address these drawbacks, Bromley later proposed an advanced model which takes into account the specificity of every ion present in the medium to evaluate the activity coefficient of an electrolyte in a binary solution. This correlation given by equation 11 can be applied for solutions with ionic strength values up to $6 \mathrm{~mol} \mathrm{~kg}^{-1}$,

$$
\log \gamma_{ \pm, m}=-A_{m}\left|z_{+} Z_{-}\right| \frac{\sqrt{I_{m}}}{1+\sqrt{I_{m}}}+\frac{\left(0.06+0.6 B_{M_{1} X_{1}}\right) I_{m}}{\left(1+\frac{1.5}{\left|z_{+} z_{-}\right|} I_{m}\right)^{2}}\left|z_{+} Z_{-}\right|+B_{M_{1} X_{1}} I_{m}
$$

where $A_{\mathrm{m}}$ is the Debye-Hückel constant for an aqueous activity coefficient with a value of $0.5098 \mathrm{~kg}^{1 / 2}$ $\mathrm{mol}^{-1 / 2}$ at $25^{\circ} \mathrm{C}$ and $B_{M_{1} X_{1}}$ a constant for the electrolyte $\mathrm{M}_{1} \mathrm{X}_{1}$. The formula can be adapted for a multicomponent system leading to equation 12 :

$$
\log \gamma_{ \pm, m}=-A_{m}\left|z_{+} z_{-}\right| \frac{\sqrt{I_{m}}}{1+\sqrt{I_{m}}}+\frac{\left|z_{+} z_{-}\right|}{\left|z_{+}\right|+\left|z_{-}\right|} \cdot\left[\frac{F_{1}}{z_{+}}+\frac{F_{2}}{z_{-}}\right]
$$

where

$$
\begin{gathered}
F_{1}=\sum_{j} \dot{B}_{M_{1} X_{j}} \bar{Z}_{M_{1} X_{j}}^{2} m_{j} \\
F_{2}=\sum_{i} \dot{B}_{M_{i} X_{1}} \bar{Z}_{M_{i} X_{1}}^{2} m_{i} \\
\dot{B}_{M_{i} X_{j}}=\frac{\left(0.06+0.6 B_{M_{i} X_{j}}\right)\left|z_{+} z_{-}\right|}{\left(1+\frac{1.5}{\left|z_{+} z_{-}\right|} I_{m}\right)^{2}}+B_{M_{i} X_{j}} \\
\bar{Z}_{M_{i} X_{j}}^{2}=\frac{\left|z_{+}\right|+\left|z_{-}\right|}{2}
\end{gathered}
$$

The $B_{M_{i} X_{j}}$ constant in Bromley model is an empirical constant which signifies the overall electrolyte contribution to the activity coefficient. It is a combination of the empirical constants for contributions of each of the individual ions $\left(B_{+}, B_{-}\right)$as also their interactions $\left(\delta_{+}, \delta_{-}\right)$. Bromley had proposed the overall electrolyte contribution $\left(B_{M_{i} X_{j}}\right)$ for a large number of electrolytes in his work (Bromley, 1973). For the electrolytes not listed in his work, the overall electrolyte contribution can be determined from the individual ion contributions $B_{+}, B_{-}, \delta_{+}$and $\delta_{-}$based on the equation 17:

$$
B_{M_{i} X_{j}}=B_{+}+B_{-}+\delta_{+} \delta_{-}
$$


The individual ion contributions $B_{+}$and $\delta_{+}$have been previously reported for the lighter lanthanides (La$\mathrm{Eu}$ ) (Bromley, 1973) and currently do not exist for the heavier lanthanides (Gd-Lu), making the applicability of the model to the entire lanthanide series difficult. Further, even for the lighter lanthanides for which the $B_{M_{i} X_{j}}$ values and the individual contributions are reported, they are not in good agreement with experimental data. Part of this problem is due to the fact that in several cases experimental data did not exist at the time of Bromley's work and therefore the individual ion contributions for those cases were estimated. Another drawback is that the $B_{M_{i} X_{j}}$ values were determined based on a model developed from isopiestic data collected over smaller data range mostly at low concentrations $\left(<1 \mathrm{~mol} \mathrm{~kg}^{-1}\right)$. Since the values at high concentrations were not available, the logarithmic nature of the function resulted in the greater error as ionic strength was increased, resulting in overestimation of activity coefficients at high ionic strengths. (Bromley, 1973) Also, the individual ion values are meant to apply to strong salts only and do not account for strong specific ion-ion chemical association at high ionic strengths $\left(\sim 3 \mathrm{~mol} \mathrm{~kg}^{-1}\right.$ and above).

To address these issues, the FY 2014 work was focused on a detailed evaluation of the Bromley parameters for the binary lanthanide nitrate electrolytes including re-calculation of the previously reported values for the lighter lanthanides and determination of the new values for the heavy lanthanides. The Bromley parameters obtained were then used to calculate the activity coefficients for the ternary lanthanide nitrate / nitric acid or sodium nitrate electrolyte systems.

\subsection{Approach}

Our aim is to obtain improved Bromley parameters for the binary 3:1 lanthanide systems, as well as the binary $1: 1 \mathrm{NaNO}_{3}$ and $\mathrm{HNO}_{3}$ at $25^{\circ} \mathrm{C}$. This is done using the following steps:

- Determination of the activity coefficients for the binary $\mathrm{Ln}\left(\mathrm{NO}_{3}\right)_{3}$ electrolytes using our water activity database generated in 2013 (Levitskaia et al., 2013). In this task, the activity coefficient data available from literature for all $\mathrm{Ln}\left(\mathrm{NO}_{3}\right)_{3}$ except $\mathrm{Ce}\left(\mathrm{NO}_{3}\right)_{3}$ were used. The literature values of activity coefficients for the respective lanthanide nitrates (Spedding, 1976; Rard, 1977; Rard, 1979; Rard, 1981; Ruas et al., 2005) were plotted versus corresponding ionic strengths, and polynomial fits were obtained. The above references were chosen as they were more recent and covered a larger range of ionic strengths compared to the ones used by Bromley (Robinson and Stokes, 1968; Wu and Hamer, 1969; Latimer, 1952 and Pitzer, 1972). The obtained polynomial fits were used to calculate activity coefficients for the binary $\mathrm{Ln}\left(\mathrm{NO}_{3}\right)_{3}$ electrolytes using our measurements. This approach was possible because of excellent agreement between our and the literature water activity results for the binary $\mathrm{Ln}\left(\mathrm{NO}_{3}\right)_{3}$ electrolytes (Levitskaia et al., 2013). For the binary $\mathrm{Ce}\left(\mathrm{NO}_{3}\right)_{3}$ electrolyte, the activity coefficients were calculated using Pitzer model as described in the section 4.1 of this report. This task resulted in the expanded database of the activity coefficients the binary $\mathrm{Ln}\left(\mathrm{NO}_{3}\right)_{3}$ electrolytes at wide concentration range.

- Determination of the Bromley parameters for the binary $\mathrm{Ln}\left(\mathrm{NO}_{3}\right)_{3}$ electrolytes. For the binary systems, the consolidated activity coefficient values (literature values as well as the values that we obtained) were fitted to Bromley's model using equation 11. For the lighter lanthanide ( $\mathrm{La}-\mathrm{Eu})$ nitrates, initially the parameters reported by Bromley (Bromley, 1973) were used for the fit. Therefore, for the $\mathrm{La}\left(\mathrm{NO}_{3}\right)_{3} / \mathrm{H}_{2} \mathrm{O}$ binary system, the reported overall electrolyte contribution $\left(B_{M_{i} X_{j}}=0.868\right)$ was used. For the remaining lighter lanthanides, the overall electrolyte contributions were not reported by Bromley. Therefore, for these, the overall contribution was calculated form the individual ion contributions using equation 2.18. As the Bromley model using his B parameters was found to overestimate the activity 
coefficients, we used the non-linear least square method to obtain the improved values of $B_{M_{i} X_{j}}$ for the lighter lanthanides. Subsequently, we used a similar approach to obtain Bromley parameters for the heavier lanthanides.

- Determination of the Bromley parameters for the binary $\mathrm{HNO}_{3}$ and $\mathrm{NaNO}_{3}$ electrolytes. The Bromley parameters for this 1:1 electrolytes are needed for the estimation of the $\mathrm{Ln}\left(\mathrm{NO}_{3}\right)_{3}$ activity coefficients in the corresponding ternary systems. In this task, combination of the literature and our data was used using similar approach described above for the binary $\mathrm{Ln}\left(\mathrm{NO}_{3}\right)_{3}$ electrolytes.

- Extension of Bromley's model for prediction of activity coefficients of the ternary $\operatorname{Ln}\left(\mathrm{NO}_{3}\right)_{3} / \mathrm{H}(\mathrm{Na}) \mathrm{NO}_{3}$ electrolytes. The obtained Bromley parameters for the binary $\mathrm{Ln}\left(\mathrm{NO}_{3}\right)_{3}$ and $\mathrm{HNO}_{3}$ or $\mathrm{NaNO}_{3}$ electrolytes were used to determine the activity coefficients of ternary systems including $\mathrm{Nd}\left(\mathrm{NO}_{3}\right)_{3} / \mathrm{HNO}_{3} / \mathrm{H}_{2} \mathrm{O} ; \mathrm{Eu}\left(\mathrm{NO}_{3}\right)_{3} / \mathrm{HNO}_{3} / \mathrm{H}_{2} \mathrm{O}$; and $\mathrm{Eu}\left(\mathrm{NO}_{3}\right)_{3} / \mathrm{NaNO}_{3} / \mathrm{H}_{2} \mathrm{O}$ using equation 12 .

\section{RESULTS}

\subsection{Bromley parameters for binary $\mathrm{Ln}\left(\mathrm{NO}_{3}\right)_{3} / \mathrm{H}_{2} \mathrm{O}$ solutions (3:1 electrolytes)}

In the original paper (Bromley, 1973), the overall electrolyte contribution $\left(\boldsymbol{B}_{\boldsymbol{M}_{\boldsymbol{i}} \boldsymbol{X}_{j}}\right.$ ) was reported only for the binary $\mathrm{La}\left(\mathrm{NO}_{3}\right)_{3} / \mathrm{H}_{2} \mathrm{O}$ system. For other lighter lanthanides $\left(\mathrm{Pr}^{3+}\right.$ through $\left.\mathrm{Eu}^{3+}\right)$, Bromley reported the individual ion contributions $(\mathrm{B}, \delta)$. We used these values to calculate the overall electrolyte contributions for the respective lanthanide nitrate salts based on the equation 18 :

$$
B_{L n\left(\mathrm{NO}_{3}\right)_{3}}=B_{\mathrm{Ln}^{3+}}+B_{\mathrm{NO}_{3}^{-}}+\delta_{\mathrm{Ln}^{3+}} \delta_{\mathrm{NO}_{3}^{-}}
$$

The $B_{M_{i} X_{j}}$ values determined using this relation is listed in Table 4.1.

Table 4.1. Tabulation of the individual $B_{L n^{3+}}$ and $\delta_{L n^{3+}}$ parameters reported by Bromley (1973) for

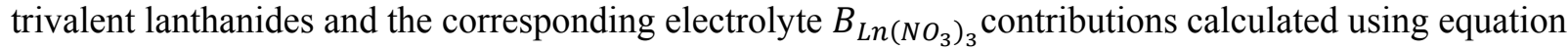
18.

\begin{tabular}{|c|c|c|c|}
\hline $\mathbf{L n}$ & $\boldsymbol{B}_{\mathbf{L n}^{3+}}$ & $\boldsymbol{\delta}_{\mathbf{L n}^{3+}}$ & $\boldsymbol{B}_{\boldsymbol{L n}\left(\boldsymbol{N O}_{\mathbf{3}}\right)_{3} \text { Bromley }}$ \\
\hline $\mathrm{La}$ & 0.036 & 0.27 & 0.0868 \\
\hline $\mathrm{Ce}$ & 0.035 & 0.27 & 0.0829 \\
\hline $\mathrm{Pr}$ & 0.034 & 0.27 & 0.0819 \\
\hline $\mathrm{Nd}$ & 0.035 & 0.27 & 0.0829 \\
\hline $\mathrm{Sm}$ & 0.039 & 0.27 & 0.0869 \\
\hline $\mathrm{Eu}$ & 0.041 & 0.27 & 0.0889 \\
\hline
\end{tabular}




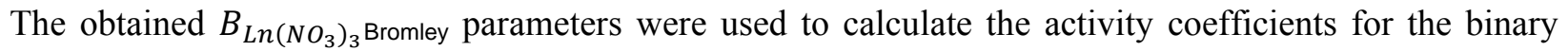
lighter $\mathrm{Ln}\left(\mathrm{NO}_{3}\right)_{3}$ electrolytes using equation 11. The comparison between experimental values of the water activities obtained from the water activity measurements and his model is shown in Figure 4.1. It is observed that Bromley's model, when used with his values for the ion contributions, overestimates the activity coefficients for all the lanthanide nitrates in general, and more so in the high concentration range $\left(3-6 \mathrm{~mol} \mathrm{~kg}^{-1}\right)$. This is attribute to the fact that contributions $(B, \delta)$ were established by Bromley at $25^{\circ} \mathrm{C}$ for a set of electrolytes (Bromley 1973) based on the limited data sets published before 1973 (Robinson and Stokes 1968; Wu and Hamer 1969; Latimer et al., 1952; Pitzer, 1972).
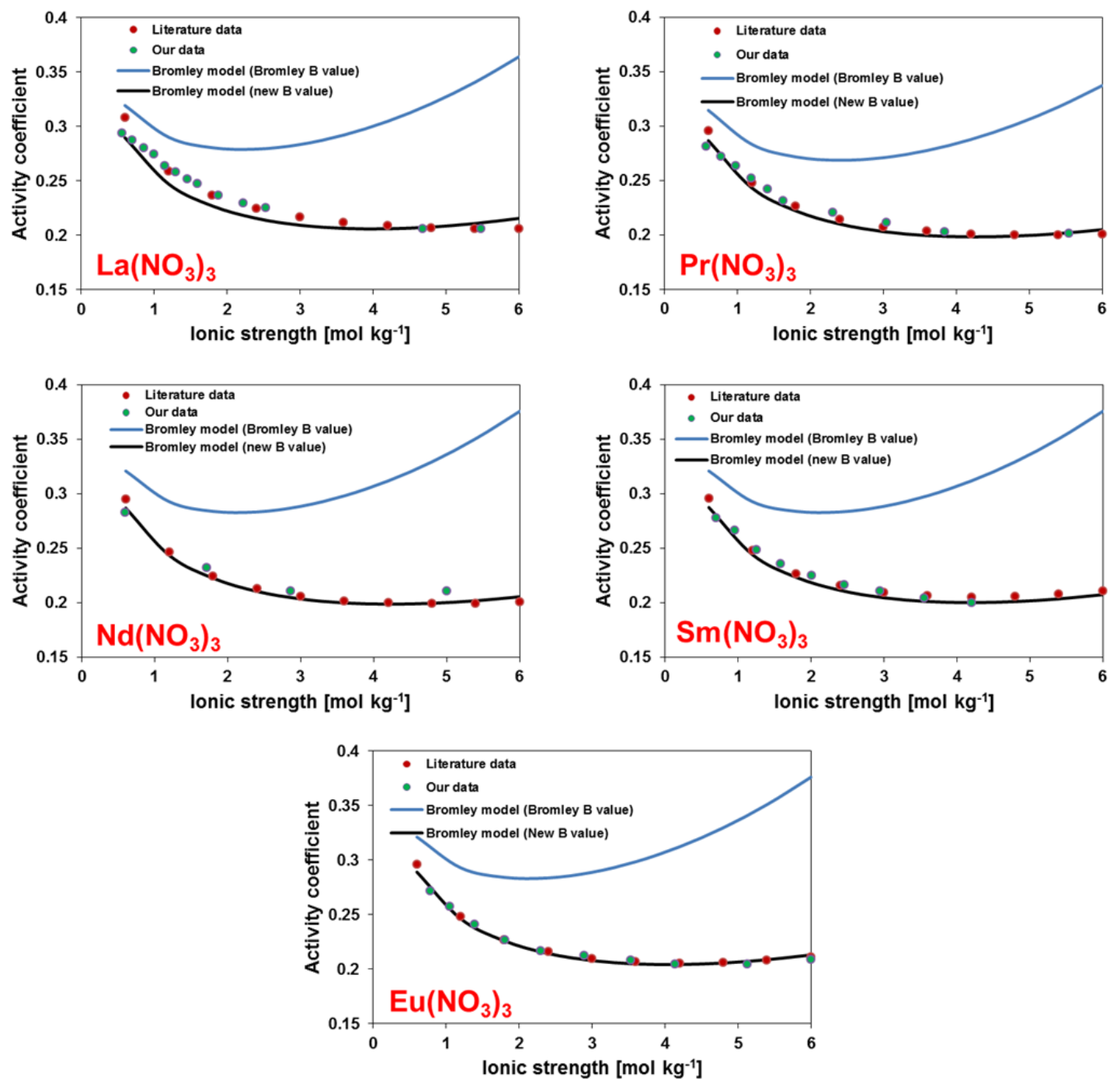

Figure 4.1. Comparison of the experimental (symbols) and calculated by the original (blue trace) or improved (black trace) Bromley's model activity coefficients for the lighter binary $\mathrm{Ln}\left(\mathrm{NO}_{3}\right)_{3}$ electrolytes. The literature data are taken from Spedding et al., 1976; Rard, et al., 1977; Rard and Spedding 1979; Rard et al., 1981. 
Lalleman (Lalleman, et al., 2012) has recently demonstrated using the $\mathrm{Nd}\left(\mathrm{NO}_{3}\right)_{3}$ and $\mathrm{NdCl}_{3}$ binary systems the that the improved $B_{M_{i} X_{j}}$ values determined using the experimental data collected over an wider range of ionic strengths provide for an accurate prediction of the activity coefficients. In this work, this approach was extended for the determination of $\mathrm{BLn}_{\left.\mathrm{LNO}_{3}\right)_{3}}$ values for the entire range of the binary $\mathrm{Ln}\left(\mathrm{NO}_{3}\right)_{3}$ electrolytes except $\mathrm{Ce}\left(\mathrm{NO}_{3}\right)_{3}$ using combination of the literature (Spedding et al., 1976; Rard et al., 1977; Rard and Spedding 1979; Rard et al., 1981) and our own experimental data (Levitskaia et al., 2013) collected over an expanded range of ionic strengths. Based on the excellent agreement of our measured values of water activities with literature data across the wide range of ionic strengths, our activity coefficient values were obtained using polynomial fits of the experimental literature values of activity coefficients versus ionic strength. The new and improved $B_{\mathrm{Ln}\left(\mathrm{NO}_{3}\right)_{3} \text { new values were determined }}$ by using non-linear least squares method by fitting equation 11 to a plot of activity coefficients versus ionic strengths. The obtained values are listed in Table 4.2.

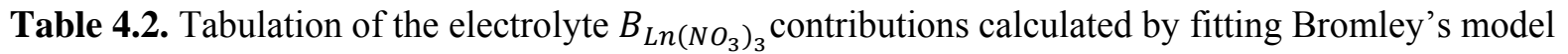
(equation 11) to activity coefficient data obtained from a combination of the literature and our data.

\begin{tabular}{|c|c|}
\hline Ln & $\boldsymbol{B}_{\boldsymbol{L n}\left(\mathbf{N O}_{3}\right)_{3} \text { new }}$ \\
\hline $\mathrm{La}$ & 0.0527 \\
\hline $\mathrm{Ce}$ & 0.0485 \\
\hline $\mathrm{Pr}$ & 0.0495 \\
\hline $\mathrm{Nd}$ & 0.0497 \\
\hline $\mathrm{Sm}$ & 0.0503 \\
\hline $\mathrm{Eu}$ & 0.052 \\
\hline $\mathrm{Gd}$ & 0.0563 \\
\hline $\mathrm{Tb}$ & 0.0621 \\
\hline $\mathrm{Dy}$ & 0.0651 \\
\hline $\mathrm{Ho}$ & 0.0679 \\
\hline $\mathrm{Er}$ & 0.0714 \\
\hline $\mathrm{Tm}$ & 0.0738 \\
\hline $\mathrm{Yb}$ & 0.0743 \\
\hline $\mathrm{Lu}$ & 0.0751 \\
\hline
\end{tabular}

It was observed that the Bromley model with the newly determined value of the salt contributions

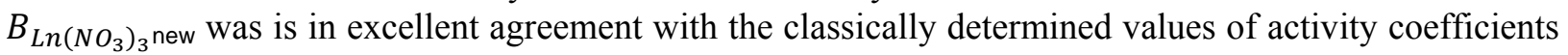
for the binary $\mathrm{Ln}\left(\mathrm{NO}_{3}\right)_{3}$ electrolytes (Figures 4.1 and 4.2). 

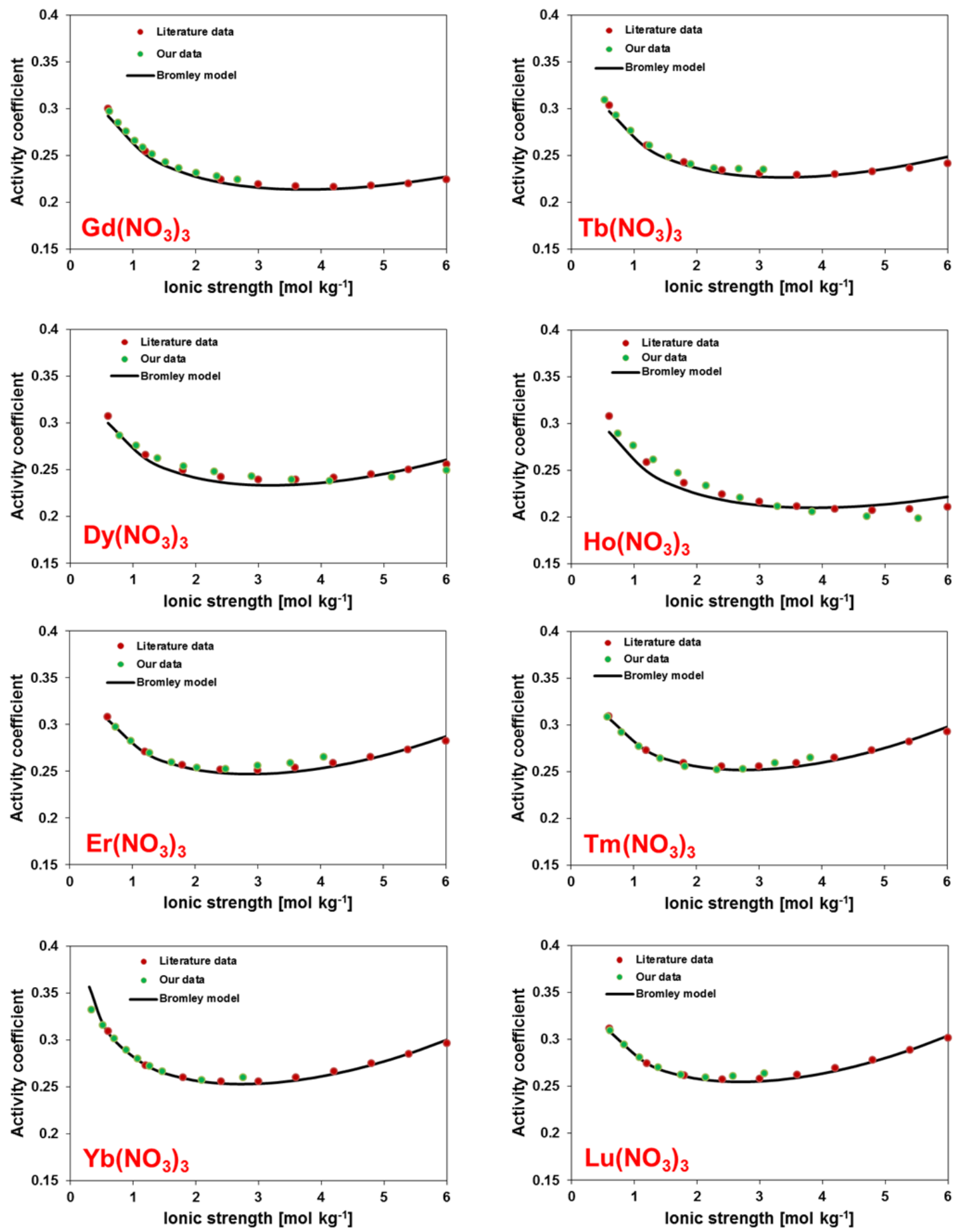

Figure 4.2. Comparison of the experimental (symbols) and calculated by the improved (black trace) Bromley's model activity coefficients for the heavier binary $\operatorname{Ln}\left(\mathrm{NO}_{3}\right)_{3}$ electrolytes. The literature data are taken from Spedding et al., 1976; Rard, et al., 1977; Rard and Spedding 1979; Rard et al., 1981. 
For the $\mathrm{Ce}\left(\mathrm{NO}_{3}\right)_{3}$ the Pitzer model was used to calculate the activity coefficient as shown in equation 19:

$$
\ln \gamma_{ \pm}=\left|z_{M} z_{X}\right| f^{\gamma}+m\left(2 v_{M} v_{X} / v\right) B_{M X}^{\gamma}+m^{2}\left[2\left(v_{M} v_{X}\right)^{3 / 2} / v\right] C_{M X}^{\gamma}
$$

where $v_{M}$ and $v_{X}$ are the numbers of $\mathrm{M}$ and $\mathrm{X}$ ions in the formula and $z_{M}$ and $z_{X}$ give their respective charges in electric units; also $v=v_{M}+v_{X}$ and $\mathrm{m}$ is the molality. The other quantities are defined as:

$$
\begin{gathered}
f^{\gamma}=-A_{\varnothing}\left[\frac{I^{1 / 2}}{1+b I^{1 / 2}}+\frac{2}{b} \ln \left(1+b I^{\frac{1}{2}}\right)\right] \\
B_{M X}^{\gamma}=2 \beta_{M X}^{(0)}+\left(2 \beta_{M X}^{(1)} / \alpha^{2} I\right)\left[1-\left(1+\alpha I^{1 / 2}-\frac{1}{2 \alpha^{2} I}\right) e^{-\alpha I^{2}}\right] \\
C_{M X}^{\gamma}=\frac{3}{2} C_{M X}^{\emptyset}
\end{gathered}
$$

In this treatment, $I$ is the ionic strength and $A_{\varnothing}$ is the Debye-Hückel coefficient which has a value of 0.391 for water at $25^{\circ} \mathrm{C}, b=1.2$ and $\alpha=2.0$. The $\beta_{M X}^{(0)}, \beta_{M X}^{(1)}$ and $C_{M X}^{\emptyset}$ correspond to the Pitzer coefficients as explained in our previous report (Levitskaia et al., 2013) and were obtained using experimental water activity data for the $\mathrm{Ce}\left(\mathrm{NO}_{3}\right)_{3}$ binary electrolyte (Table 4.3).

Table 4.3. Pitzer parameters for the $\mathrm{Ce}\left(\mathrm{NO}_{3}\right)_{3}$ binary electrolyte.

\begin{tabular}{|c|c|c|}
\hline \multicolumn{3}{|c|}{ Pitzer parameters for the $\mathrm{Ce}\left(\mathrm{NO}_{3}\right)_{3}$ binary electrolyte } \\
\hline$\beta_{M X}^{(0)}$ & $\beta_{M X}^{(1)}$ & $C_{M X}^{\varnothing}$ \\
\hline 0.43 & 6.1 & -0.05 \\
\hline
\end{tabular}

The obtained Pitzer parameters were applied to calculate the activity coefficient values for the $\mathrm{Ce}\left(\mathrm{NO}_{3}\right)_{3}$

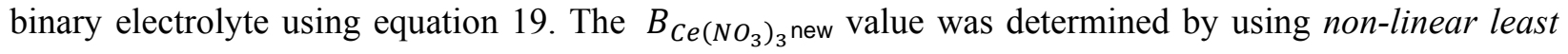
squares method by fitting equation 11 to a plot of the activity coefficients versus ionic strengths (Table 4.2). It was observed that the Bromley's model accurately predicted the $\mathrm{Ce}\left(\mathrm{NO}_{3}\right)_{3}$ binary activity coefficients (Figure 4.3). 


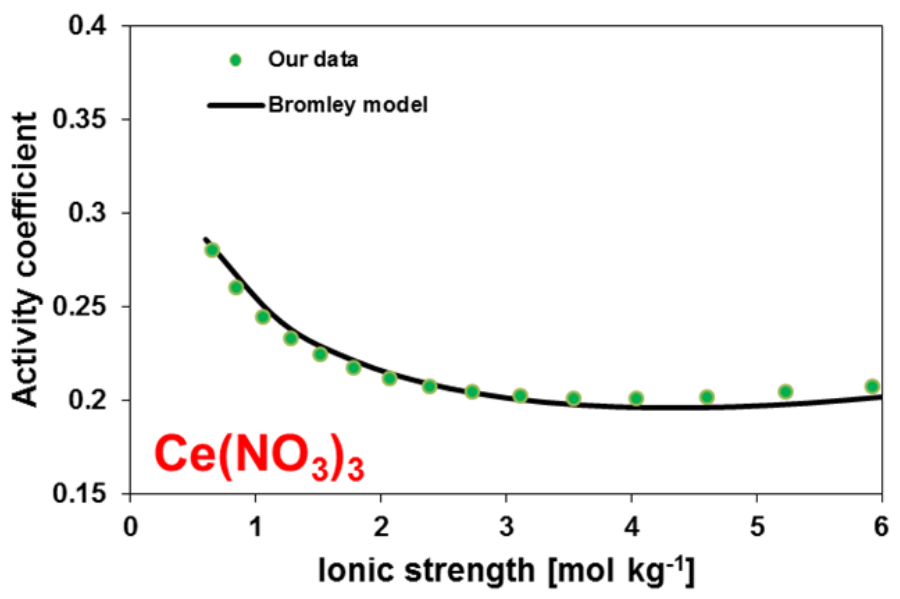

Figure 4.3. Comparison of the experimental (symbols) and calculated by the improved (black trace) Bromley's model activity coefficients for the binary $\mathrm{Ce}\left(\mathrm{NO}_{3}\right)_{3}$ electrolyte.

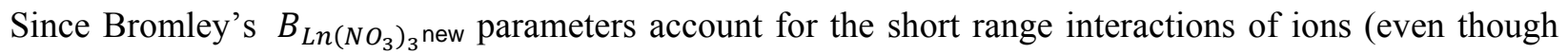
empirically), it is of interest to examine their dependence on the ionic radii of the lanthanides (Figure 4.4).

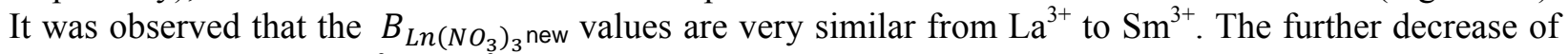

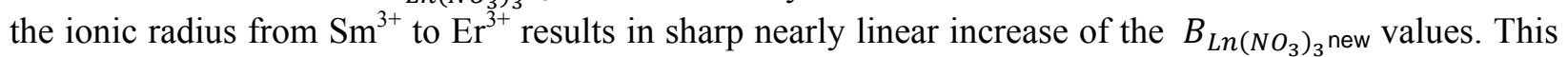

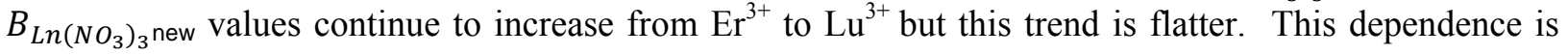
attributed to the interplay between the ionic radii, coordination number and the coordination sphere of the lanthanides. The sharp difference in the $B_{L n}\left(\mathrm{NO}_{3}\right)_{3}$ new values for the $\mathrm{La}^{3+}-\mathrm{Sm}^{3+}$ group and the rest of the lanthanides maybe rationalized based on the consideration that this lighter lanthanides are nine coordinated in water while the heavy lanthanides are preferentially eight coordinated (Bonal et al., 1998). For the first four lanthanides, the lanthanide coordination sphere and the ionic radii allow an equal number of nitrate ions to be accommodated within the inner sphere with equal ease, which is reflected in the similar $\mathrm{BLn}_{\mathrm{LNO}} \mathrm{N}_{3}$ new values. Subsequently, from $\mathrm{Sm}^{3+}$ to $\mathrm{Er}^{3+}$, as the ionic radius and the coordination number decreases, the ease of accommodating nitrate ions within the inner sphere becomes increasingly difficult due to the competition with the hydration water, which is reflected in the marked rise in

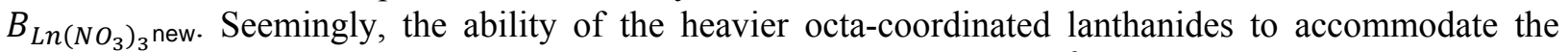
nitrate ions within the inner sphere reaches maximum capacity for $\mathrm{Er}^{3+}$ which still shows nitrate ions bound in bidentate manner, the total coordination number of $\mathrm{Er}^{3+}$ being 8 . But, on further decreasing the cation radius, it gets progressively difficult for the nitrate anion to penetrate the inner sphere of the trivalent lanthanide cation. Thus, the complexes formed with the last members of the lanthanide series can possibly be partially of the outer-sphere type (Bonal et al., 1998). This has been suggested by Raman studies of aqueous lanthanide nitrate solutions in the glassy state (Kanno et al., 1984), showing that for $\mathrm{Tm}^{3+}, \mathrm{Yb}^{3+}$ and $\mathrm{Lu}^{3+}$, the inner-sphere coordination is entirely comprised of water molecules. 


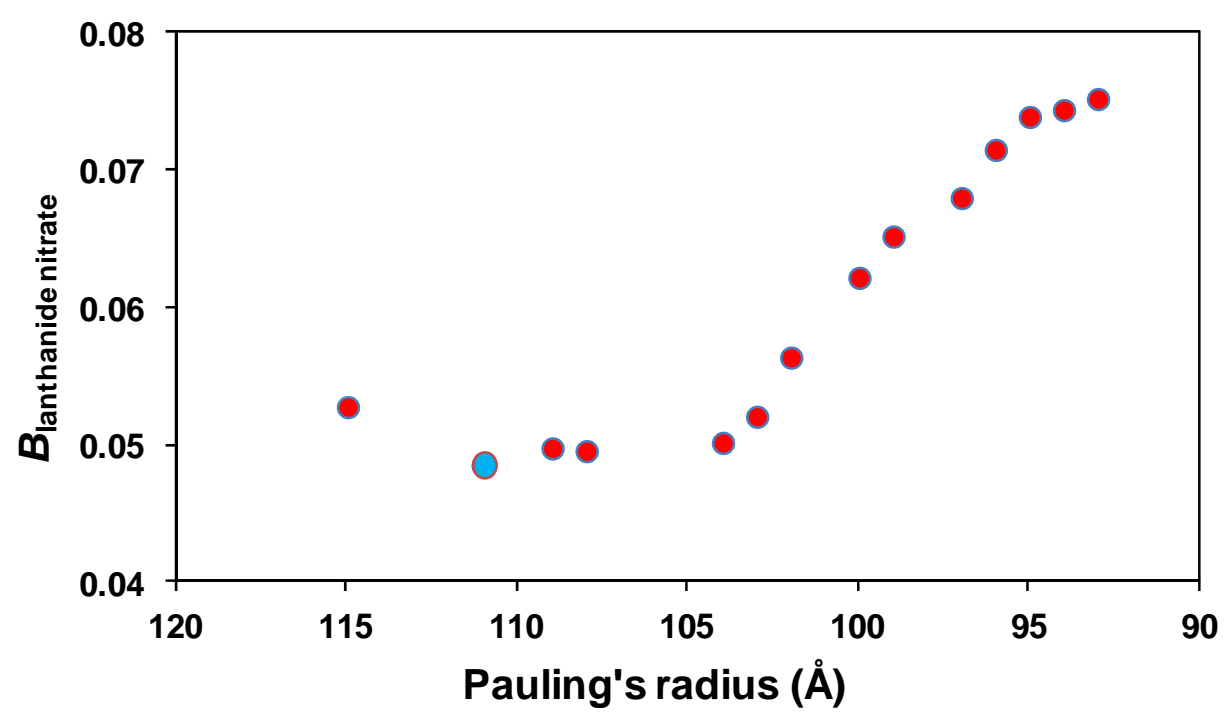

Figure 4.4. A plot of $B_{\left.\mathrm{Ln}_{(} \mathrm{NO}_{3}\right)_{3}}$ versus the ionic radii. The $\mathrm{Ce}^{3+}$ data point is marked with a blue circle to differentiate it from the rest of the lanthanides as its activity coefficient was obtained based solely on our data using Pitzer treatment.

\subsection{Bromley parameters for binary $\mathrm{HNO}_{3} / \mathrm{H}_{2} \mathrm{O}$ and $\mathrm{NaNO}_{3} / \mathrm{H}_{2} \mathrm{O}$ solutions (1:1 electrolytes)}

The extension of the Bromley model to ternary $\mathrm{Ln}\left(\mathrm{NO}_{3}\right)_{3} / \mathrm{H}(\mathrm{Na}) \mathrm{NO}_{3} / \mathrm{H}_{2} \mathrm{O}$ systems requires availability of the activity coefficients for the $\mathrm{HNO}_{3} / \mathrm{H}_{2} \mathrm{O}$ and the $\mathrm{NaNO}_{3} / \mathrm{H}_{2} \mathrm{O}$ binary systems, and an accurate estimation of the respective $\boldsymbol{B}_{\boldsymbol{M}_{\boldsymbol{i}} \boldsymbol{X}_{\boldsymbol{j}}}$ values.

For the $\mathrm{HNO}_{3}$ binary electrolyte, activity coefficients calculated by equation 11 using previously reported Bromley parameter $\boldsymbol{B}_{\mathrm{HNO}_{3}}=0.0776$ (Bromley 1973) are in good agreement with the literature (Charrin et al., 1999) and our data in the ionic strength range of $0-6 \mathrm{~mol} \mathrm{~kg}^{-1}$ (Figure 4.5). 


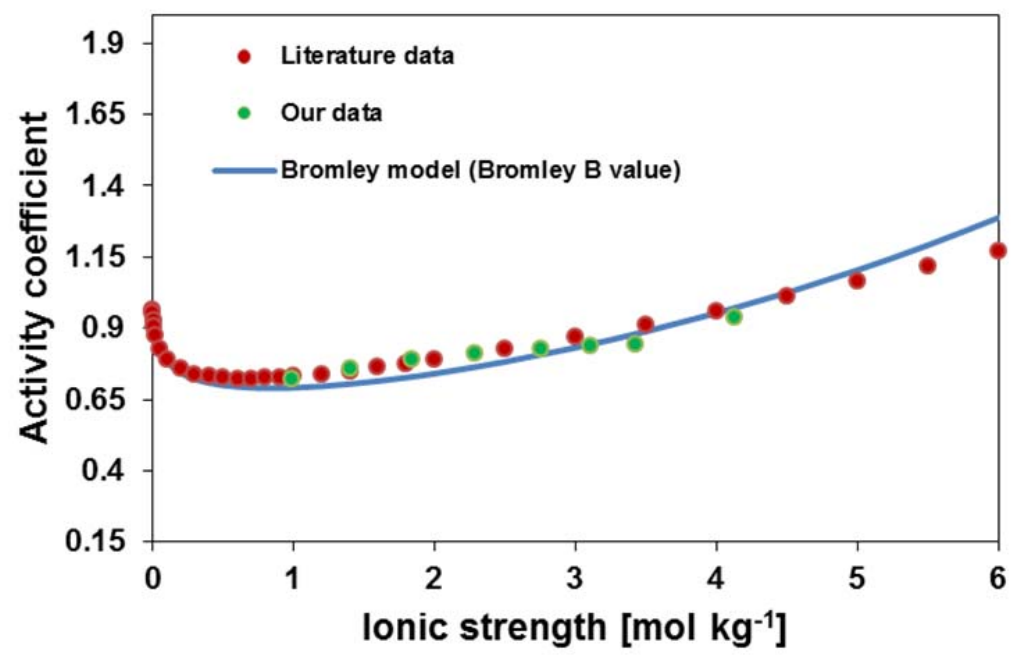

Figure 4.5. Comparison of the $\mathrm{HNO}_{3}$ activity coefficients calculated using Bromley's model $\left(\boldsymbol{B}_{\mathrm{HNO}_{3}}=\right.$ 0. 0776) with the literature (Charrin et al., 1999) and our experimental values.

Similarly, an overall electrolyte contribution of $\boldsymbol{B}_{\mathrm{NaNO}_{3}}=-0.0128$ reported for the $\mathrm{NaNO}_{3}$ binary | electrolyte (Bromley, 1973) accurately predicted the experimental activity coefficients obtained from the literature (Marcos-Aroyo et al., 1996) as well as our experimentation (Figure 4.6).

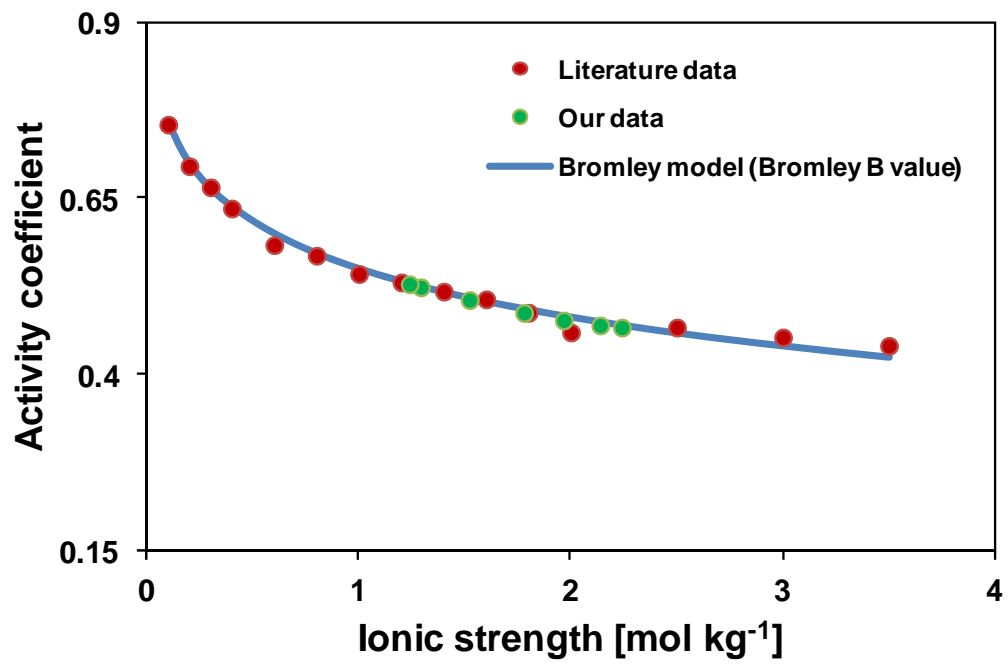

Figure 4.6. Comparison of the $\mathrm{NaNO}_{3}$ activity coefficients calculated using Bromley's model $\left(\boldsymbol{B}_{\mathrm{NaNO}_{3}}=\right.$ -0.0128) with the literature (Marcos-Aroyo et al., 1996) and our experimental data. 


\subsection{Water Activity Measurements and Activity Coefficients for the Ternary $\mathrm{Ln}\left(\mathrm{NO}_{3}\right)_{3} / \mathrm{H}(\mathrm{Na}) \mathrm{NO}_{3} / \mathrm{H}_{2} \mathrm{O}$ Systems}

Based on the ability of the new Bromley models to accurately predict the binary $\operatorname{Ln}\left(\mathrm{NO}_{3}\right)_{3}$ activity coefficients, this method was extended to the ternary $\mathrm{Ln}\left(\mathrm{NO}_{3}\right)_{3} / \mathrm{H}(\mathrm{Na}) \mathrm{NO}_{3} / \mathrm{H}_{2} \mathrm{O}$ systems. Measurements of the water activity of the ternary $\mathrm{Nd}\left(\mathrm{NO}_{3}\right)_{3} / \mathrm{HNO}_{3}, \mathrm{Eu}\left(\mathrm{NO}_{3}\right)_{3} / \mathrm{HNO}_{3}$, and $\mathrm{Eu}\left(\mathrm{NO}_{3}\right)_{3} / \mathrm{NaNO}_{3}$ electrolytes were performed using the Novasina water activity instrument equipped with filters that protected against acid vapors at elevated nitric acid concentration. The experimental conditions chosen were a nearly constant $2 \mathrm{M} \mathrm{HNO}_{3}$ or $\mathrm{NaNO}_{3}$ and variable $\mathrm{Ln}\left(\mathrm{NO}_{3}\right)_{3}$ concentrations, so that it would be possible to examine the effect of $\mathrm{Nd}^{3+}$ and $\mathrm{NO}_{3}{ }^{-}$concentrations on the water activity in isolation from the $\mathrm{H}^{+}$species. In the $\mathrm{Eu}\left(\mathrm{NO}_{3}\right)_{3} / \mathrm{NaNO}_{3}$ system, the concentration of both electrolytes were varied.

\subsection{1 $\mathrm{Nd}\left(\mathrm{NO}_{3}\right)_{3} / \mathrm{HNO}_{3} / \mathrm{H}_{2} \mathrm{O}$ system}

Experimental water activity values for the $\mathrm{Nd}\left(\mathrm{NO}_{3}\right)_{3} / \mathrm{HNO}_{3} / \mathrm{H}_{2} \mathrm{O}$ ternary system are presented in Table 4.4. It is observed that as the ionic strength of the solution increases from $\sim 2$ to $\sim 5 \mathrm{~mol} \mathrm{~kg}^{-1}$, the water activity gradually decreases. The trend is in agreement with the literature data (Lalleman et al., 2012) demonstrating the consistent decrease of water activity with the increase of ionic strength from 3.68 to $8.53 \mathrm{~mol} \mathrm{~kg}^{-1}$ (Figure 4.7).

Table 4.4. Water activity and $\mathrm{Nd}\left(\mathrm{NO}_{3}\right)_{3}$ activity coefficients for the $\mathrm{Nd}\left(\mathrm{NO}_{3}\right)_{3} / \mathrm{HNO}_{3} / \mathrm{H}_{2} \mathrm{O}$ ternary system. The activity coefficients $\gamma_{ \pm}$were calculated using the Bromley's model by equation 12 .

\begin{tabular}{|c|c|c|c|c|c|}
\hline $\begin{array}{c}m_{\mathrm{Nd}\left(\mathrm{NO}_{3}\right)_{3}}^{\operatorname{mixt}} \\
\mathrm{mol} \mathrm{kg}^{-1}\end{array}$ & $\begin{array}{c}m_{H N O_{3}}^{\operatorname{mixt}} \\
\mathrm{mol} \mathrm{kg}^{-1}\end{array}$ & $\begin{array}{c}I_{\mathrm{m}} \\
\mathrm{mol} \mathrm{kg}{ }^{-1}\end{array}$ & $\begin{array}{c}\text { Density } \\
\mathrm{g} \mathrm{cm}^{3}\end{array}$ & $\mathrm{~A}_{\mathrm{w}}$ & $\gamma_{ \pm}^{\mathrm{Nd}\left(\mathrm{NO}_{3}\right)_{3} / \mathrm{HNO}_{3} / \mathrm{H} 2 \mathrm{O}}$ \\
\hline 0.5000 & 1.9998 & 4.9997 & 1.1791 & 0.886 & 0.2125 \\
\hline 0.2499 & 2.0014 & 3.5007 & 1.1206 & 0.906 & 0.2167 \\
\hline 0.1000 & 2.0044 & 2.6041 & 1.0848 & 0.918 & 0.2294 \\
\hline 0.0750 & 2.0004 & 2.4504 & 1.0784 & 0.921 & 0.2327 \\
\hline 0.0500 & 2.0002 & 2.3002 & 1.0714 & 0.922 & 0.2365 \\
\hline 0.0250 & 2.0005 & 2.1505 & 1.0665 & 0.924 & 0.2409 \\
\hline 0.0100 & 2.0012 & 2.0612 & 1.0626 & 0.926 & 0.2438 \\
\hline 0.0075 & 2.0018 & 2.0467 & 1.0609 & 0.925 & 0.2444 \\
\hline 0.0050 & 1.9994 & 2.0294 & 1.0611 & 0.927 & 0.2449 \\
\hline 0.0025 & 1.9986 & 2.0136 & 1.0609 & 0.927 & 0.2454 \\
\hline 0.0010 & 2.0008 & 2.0068 & 1.0608 & 0.927 & 0.2457 \\
\hline
\end{tabular}




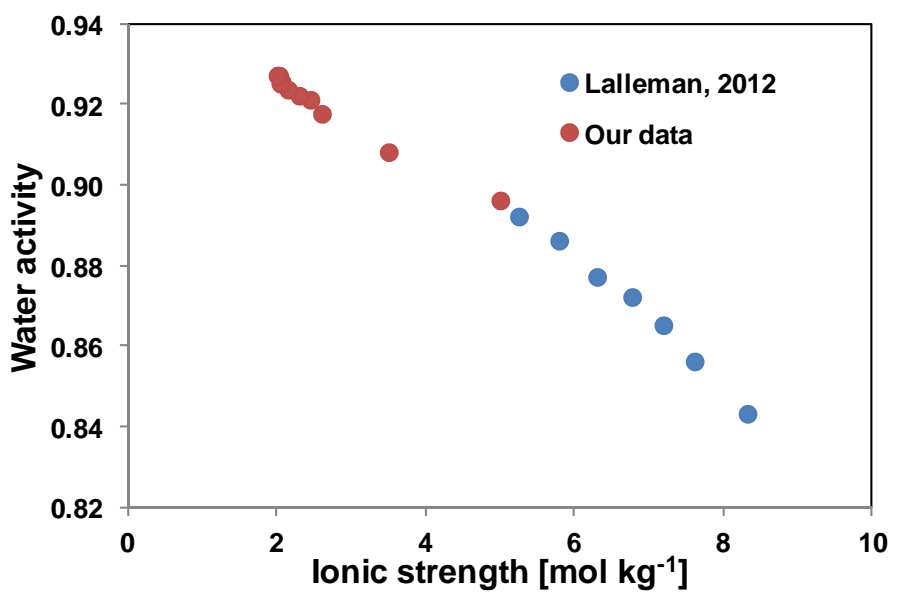

Figure 4.7. Plot of the water activity versus the ionic strength for $\mathrm{Nd}\left(\mathrm{NO}_{3}\right)_{3} / \mathrm{HNO}_{3} / \mathrm{H}_{2} \mathrm{O}$ ternary system

A comparison of the water activities for the $\mathrm{Nd}\left(\mathrm{NO}_{3}\right)_{3} / \mathrm{HNO}_{3} / \mathrm{H}_{2} \mathrm{O}$ ternary system with the $\mathrm{Nd}\left(\mathrm{NO}_{3}\right)_{3} /$ $\mathrm{H}_{2} \mathrm{O}$ binary system shows that for both the systems, the decrease in water activity with increase in ionic strength follows a similar slope (Figure 4.8). It is also worth noting that the water activities for the ternary systems are always consistently less than the binary systems by $\sim 0.06$ units. The identical nature of the variation of the water activity of the ternary system with the binary system suggests that the nitric acid provides a constant contribution to the overall solution water activity term.

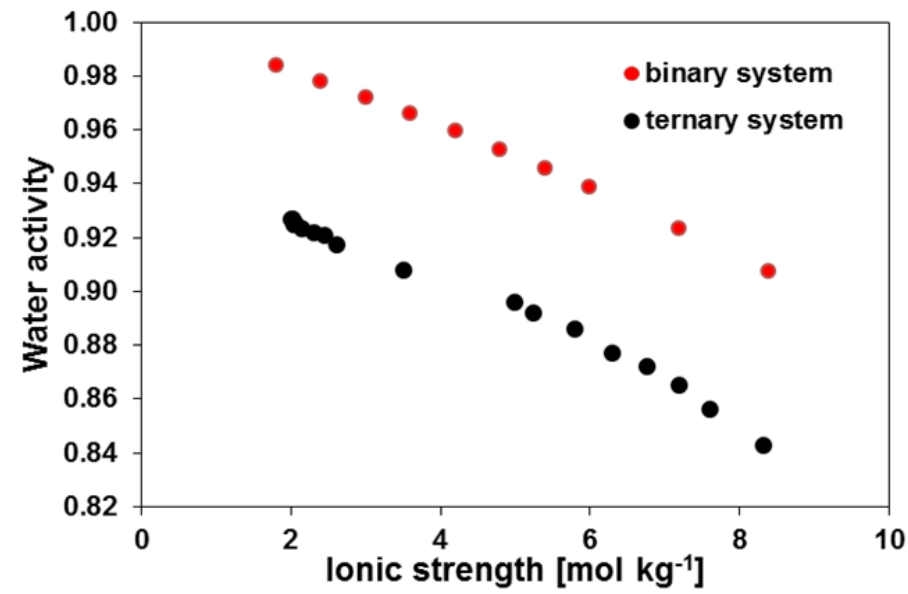

Figure 4.8. Comparison of water activities for the $\mathrm{Nd}\left(\mathrm{NO}_{3}\right)_{3} / \mathrm{HNO}_{3} / \mathrm{H}_{2} \mathrm{O}$ ternary system with the $\mathrm{Nd}\left(\mathrm{NO}_{3}\right)_{3} / \mathrm{H}_{2} \mathrm{O}$ binary system.

To determine the $\mathrm{Nd}\left(\mathrm{NO}_{3}\right)_{3}$ activity coefficients in the ternary system, the $B_{\mathrm{Nd}\left(\mathrm{NO}_{3}\right)_{3} \text { new }}=0.0497$ and $B_{\mathrm{HNO}_{3}}=0.0776$ constants for the binary $\mathrm{Nd}\left(\mathrm{NO}_{3}\right)_{3}$ and $\mathrm{HNO}_{3}$ electrolytes were used in equation 12 . The activity coefficients obtained (Table 4.4) decrease as the ionic strength increases from $\sim 2$ to $\sim 4 \mathrm{~mol} \mathrm{~kg}^{-1}$ (Figure 4.9). Again it was observed that the activity coefficients obtained in this work agree with the literature results (Lalleman et al., 2012) at the complimentary higher values of the ionic strength. 


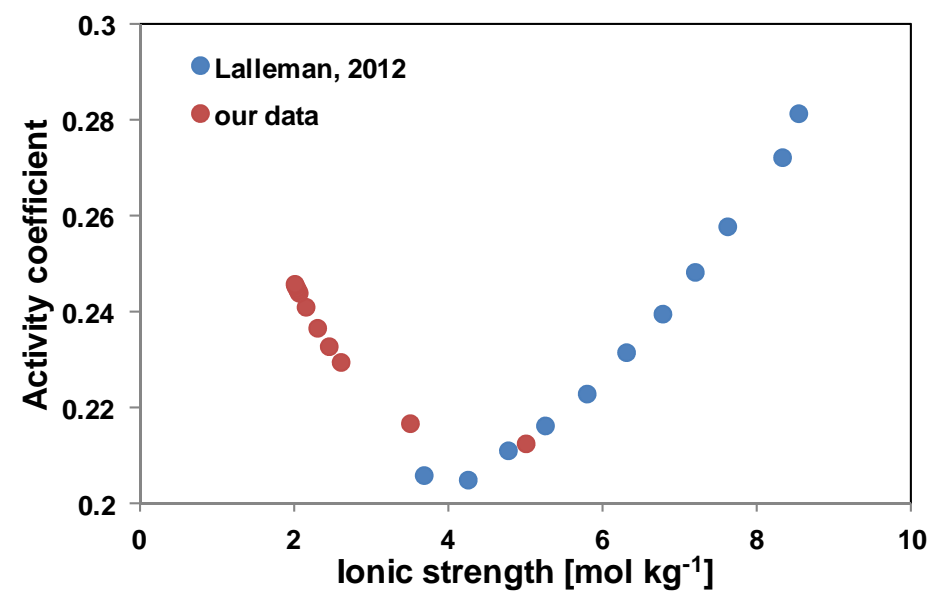

Figure 4.9. Plot of activity coefficients versus the ionic strength for the $\mathrm{Nd}\left(\mathrm{NO}_{3}\right)_{3} / \mathrm{HNO}_{3} / \mathrm{H}_{2} \mathrm{O}$ ternary system.

An overlay of the activity coefficients for the $\mathrm{Nd}\left(\mathrm{NO}_{3}\right)_{3} / \mathrm{HNO}_{3} / \mathrm{H}_{2} \mathrm{O}$ ternary and $\mathrm{Nd}\left(\mathrm{NO}_{3}\right)_{3} / \mathrm{H}_{2} \mathrm{O}$ binary systems as a function of the ionic strength show similar trends for the dilute solutions so that the activity coefficient decreasing with the ionic strength up to approximately $4.0 \mathrm{~mol} \mathrm{~kg}^{-1}$ (Figure 4.10). The comparable magnitude of the $\mathrm{Nd}\left(\mathrm{NO}_{3}\right)_{3}$ activity coefficients in the moderately concentrated ternary and binary systems suggests that the nature of the ionic interaction (short range interactions and associations) in both systems is similar. For the solutions with the ionic strength above $4.0 \mathrm{~mol} \mathrm{~kg}^{-1}$, the $\mathrm{Nd}\left(\mathrm{NO}_{3}\right)_{3}$ activity coefficients demonstrate steep increase in the ternary system while they increase only gradually in the binary system. This indicates significantly stronger ionic interactions in the ternary system as compared to the binary one.

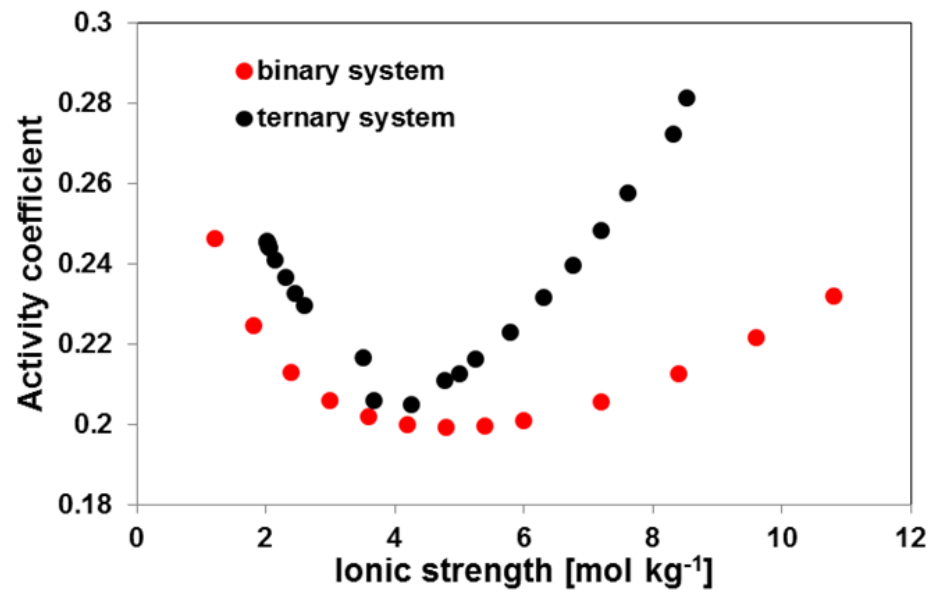

Figure 4.10. Comparison of the $\mathrm{Nd}\left(\mathrm{NO}_{3}\right)_{3}$ activity coefficients for $\mathrm{Nd}\left(\mathrm{NO}_{3}\right)_{3} / \mathrm{HNO}_{3} / \mathrm{H}_{2} \mathrm{O}$ ternary and $\mathrm{Nd}\left(\mathrm{NO}_{3}\right)_{3} / \mathrm{H}_{2} \mathrm{O}$ binary systems. 


\subsection{2 $\mathrm{Eu}\left(\mathrm{NO}_{3}\right)_{3} / \mathrm{HNO}_{3} / \mathrm{H}_{2} \mathrm{O}$ system}

The experimental water activity values for the ternary $\mathrm{Eu}\left(\mathrm{NO}_{3}\right)_{3} / \mathrm{HNO}_{3}$ electrolyte are shown in Table 4.5 and Figure 4.11.

Table 4.5. Water activity and $\mathrm{Eu}\left(\mathrm{NO}_{3}\right)_{3}$ activity coefficients for the $\mathrm{Eu}\left(\mathrm{NO}_{3}\right)_{3} / \mathrm{HNO}_{3} / \mathrm{H}_{2} \mathrm{O}$ ternary system. The activity coefficients $\gamma_{ \pm}$were calculated using the Bromley's model by equation 12 .

\begin{tabular}{|c|c|c|c|c|c|}
\hline $\begin{array}{c}\mathrm{m}_{\mathrm{Eu}\left(\mathrm{NO}_{3}\right)_{3}}^{\mathrm{mixt}} \\
\mathrm{mol} \mathrm{kg}\end{array}$ & $\begin{array}{c}\mathrm{m}_{\mathrm{HNO}_{3}}^{\mathrm{mixt}} \\
\mathrm{mol} \mathrm{\textrm {kg } ^ { - 1 }}\end{array}$ & $\begin{array}{c}I_{\mathrm{m}} \\
\mathrm{mol} \mathrm{kg}\end{array}$ & $\begin{array}{c}\text { Density } \\
\mathrm{g} \mathrm{cm}^{3}\end{array}$ & $\mathrm{~A}_{\mathrm{w}}$ & $\gamma_{ \pm}^{\mathrm{Eu}\left(\mathrm{NO}_{3}\right)_{3} / \mathrm{HNO}_{3} / \mathrm{H}_{2 O}}$ \\
\hline 0.4999 & 2.0002 & 4.9995 & 1.1791 & 0.866 & 0.2778 \\
\hline 0.2499 & 1.9981 & 3.4972 & 1.1211 & 0.906 & 0.2758 \\
\hline 0.1000 & 2.0033 & 2.6034 & 1.0844 & 0.918 & 0.2885 \\
\hline 0.0750 & 1.9997 & 2.4497 & 1.0789 & 0.919 & 0.2919 \\
\hline 0.0500 & 2.0002 & 2.3002 & 1.0725 & 0.922 & 0.2959 \\
\hline 0.0250 & 2.0003 & 2.1502 & 1.0660 & 0.922 & 0.3005 \\
\hline 0.0100 & 2.0017 & 2.0617 & 1.0624 & 0.924 & 0.3035 \\
\hline 0.0075 & 1.9993 & 2.0443 & 1.0621 & 0.924 & 0.3040 \\
\hline 0.0050 & 1.9984 & 2.0284 & 1.0614 & 0.924 & 0.3045 \\
\hline 0.0025 & 1.9981 & 2.0131 & 1.0603 & 0.925 & 0.3051 \\
\hline 0.0010 & 1.9999 & 2.0059 & 1.0593 & 0.925 & 0.3054 \\
\hline
\end{tabular}

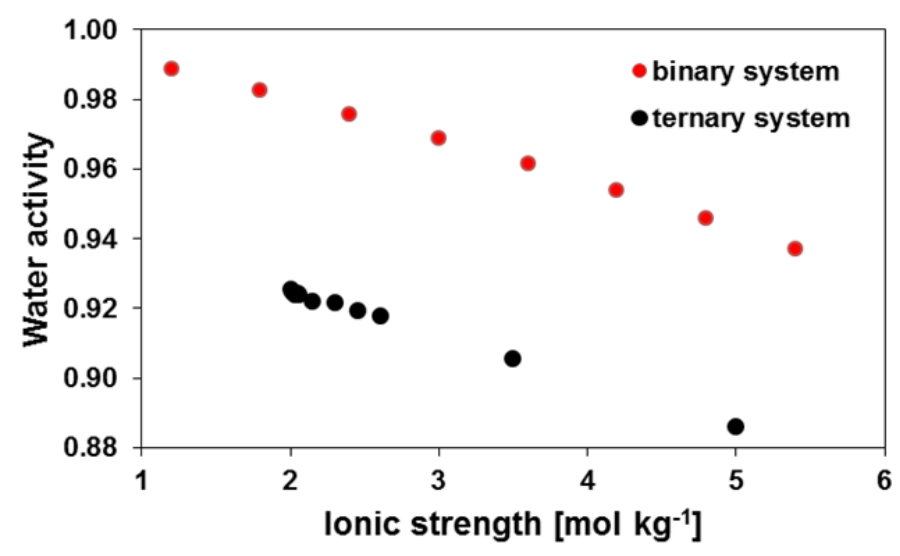

Figure 4.11. Comparison of the water activity in the $\mathrm{Eu}\left(\mathrm{NO}_{3}\right)_{3} / \mathrm{HNO}_{3} / \mathrm{H}_{2} \mathrm{O}$ ternary and $\mathrm{Eu}\left(\mathrm{NO}_{3}\right)_{3} / \mathrm{H}_{2} \mathrm{O}$ binary systems.

Similar to the $\mathrm{Nd}\left(\mathrm{NO}_{3}\right)_{3}$ system, a comparison of the water activities for the $\mathrm{Eu}\left(\mathrm{NO}_{3}\right)_{3} / \mathrm{HNO}_{3} / \mathrm{H}_{2} \mathrm{O}$ ternary system with those for the $\mathrm{Eu}\left(\mathrm{NO}_{3}\right)_{3} / \mathrm{H}_{2} \mathrm{O}$ binary system shows that for both the systems, the decrease in water activity with increase in ionic strength follows a similar slope with the offset of about 0.065 . 
The $\mathrm{Eu}\left(\mathrm{NO}_{3}\right)_{3}$ activity coefficients for the ternary $\mathrm{Eu}\left(\mathrm{NO}_{3}\right)_{3} / \mathrm{HNO}_{3}$ electrolyte were calculated using the $B_{E u\left(N O_{3}\right)_{3} \text { new }}=0.052$ and $B_{\mathrm{HNO}_{3}}=0.0776$ constants for the binary $\mathrm{Eu}\left(\mathrm{NO}_{3}\right)_{3}$ and $\mathrm{HNO}_{3}$ electrolytes in equation 12. The $\mathrm{Eu}\left(\mathrm{NO}_{3}\right)_{3}$ activity coefficients plotted as a function of the solution total ionic strength show a decrease as the ionic strength increases from $\sim 2$ to $\sim 3.5 \mathrm{~mol} \mathrm{~kg}^{-1}$ (Figure 4.12). Additional experimental data are needed to evaluate the $\mathrm{Eu}\left(\mathrm{NO}_{3}\right)_{3}$ activity coefficients in the ternary system at higher ionic strength.

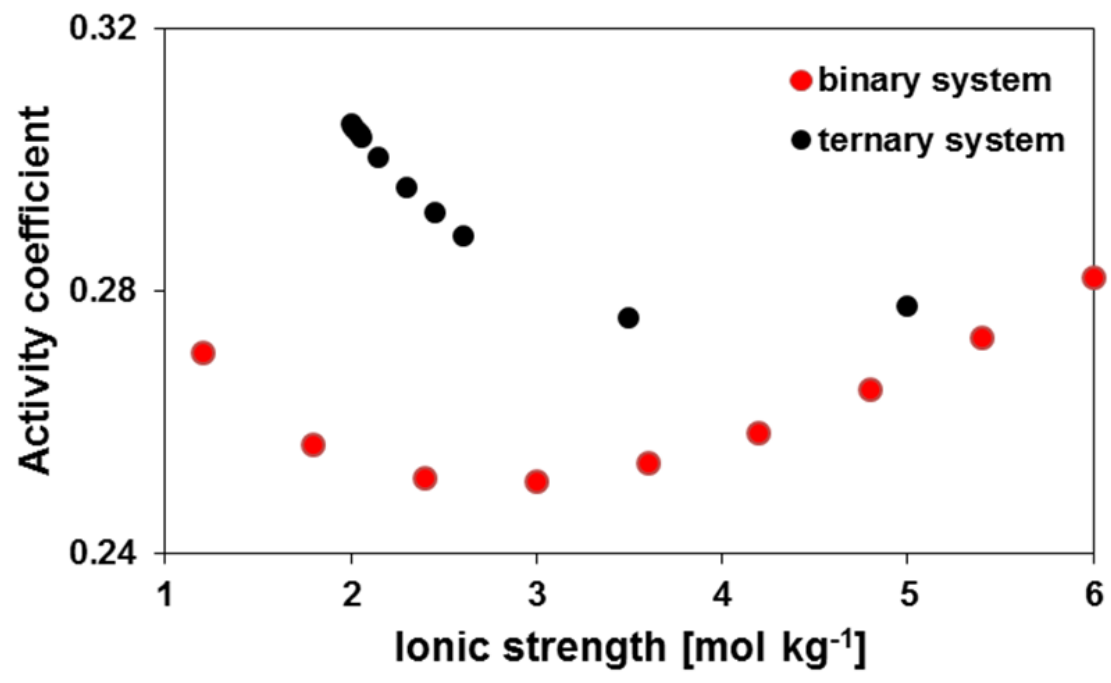

Figure 4.12. Comparison of the $\mathrm{Eu}\left(\mathrm{NO}_{3}\right)_{3}$ activity coefficients in the $\mathrm{Eu}\left(\mathrm{NO}_{3}\right)_{3} / \mathrm{HNO}_{3} / \mathrm{H}_{2} \mathrm{O}$ ternary and $\mathrm{Eu}\left(\mathrm{NO}_{3}\right)_{3} / \mathrm{H}_{2} \mathrm{O}$ binary systems.

An overlay of the $\mathrm{Eu}\left(\mathrm{NO}_{3}\right)_{3}$ activity coefficients in the $\mathrm{Eu}\left(\mathrm{NO}_{3}\right)_{3} / \mathrm{HNO}_{3} / \mathrm{H}_{2} \mathrm{O}$ ternary system and $\mathrm{Eu}\left(\mathrm{NO}_{3}\right)_{3} / \mathrm{H}_{2} \mathrm{O}$ binary systems shows some similarity in trends of the activity coefficient initially dropping with ionic strength up to $\sim 3.5-4.0 \mathrm{~mol} \mathrm{~kg}^{-1}$ followed by it subsequently increasing with ionic strength. However, the slopes for both the decrease and the subsequent increase are significantly steeper for the ternary system compared to the binary system. Similar to the $\mathrm{Nd}\left(\mathrm{NO}_{3}\right)_{3} / \mathrm{HNO}_{3} / \mathrm{H}_{2} \mathrm{O}$ system, the fact that the magnitude of the activity coefficients of the ternary systems are comparable with those of the binary, is suggestive that the ionic interaction (short range interactions and associations) in the ternary system is comparable to the binary system.

\subsection{3 $\mathrm{Eu}\left(\mathrm{NO}_{3}\right)_{3} / \mathrm{NaNO}_{3} / \mathrm{H}_{2} \mathrm{O}$ system}

The experimental water activity values for the ternary $\mathrm{Eu}\left(\mathrm{NO}_{3}\right)_{3} / \mathrm{NaNO}_{3}$ electrolyte are shown in Table 4.6 and Figure 4.13. Similar to the other ternary systems, the water activity in the $\mathrm{Eu}\left(\mathrm{NO}_{3}\right)_{3} / \mathrm{NaNO}_{3} / \mathrm{H}_{2} \mathrm{O}$ system gradually decreased as the solution total ionic strength increased from $\sim 2.7$ to $\sim 6.7 \mathrm{~mol} \mathrm{~kg}^{-1}$. This decrease was nearly identical to that of observed for the $\mathrm{Eu}\left(\mathrm{NO}_{3}\right)_{3} / \mathrm{H}_{2} \mathrm{O}$ binary system with the offset of about 0.015 (Figure 4.13). In comparison this offset was significantly larger (about 0.065) for the $\mathrm{Eu}\left(\mathrm{NO}_{3}\right)_{3} / \mathrm{HNO}_{3} / \mathrm{H}_{2} \mathrm{O}$ ternary system. 
Table 4.6. Water activity and $\mathrm{Eu}\left(\mathrm{NO}_{3}\right)_{3}$ activity coefficients for the $\mathrm{Eu}\left(\mathrm{NO}_{3}\right)_{3} / \mathrm{NaNO}_{3} / \mathrm{H}_{2} \mathrm{O}$ ternary system. The activity coefficients $\gamma_{ \pm}$were calculated using the Bromley's model by equation 12 .

\begin{tabular}{|c|c|c|c|c|}
\hline $\begin{array}{c}m_{\mathrm{Eu}\left(\mathrm{NO}_{3}\right)_{3}}^{\operatorname{mixt}} \\
\mathrm{mol} \mathrm{kg}{ }^{-1}\end{array}$ & $\begin{array}{l}m_{\text {NaNO }_{3}}^{\operatorname{mixt}} \\
\mathrm{mol} \mathrm{kg}^{-1}\end{array}$ & $\begin{array}{c}I_{\mathrm{m}} \\
\mathrm{mol} \mathrm{kg}^{-1}\end{array}$ & $\mathrm{~A}_{\mathrm{w}}$ & $\gamma_{ \pm}^{\mathrm{Eu}\left(\mathrm{NO}_{3}\right)_{3} / \mathrm{NaNO}_{3} / \mathrm{H} 2 \mathrm{O}}$ \\
\hline 0.3370 & 0.7762 & 2.7982 & 0.966 & 0.2104 \\
\hline 0.3519 & 0.8104 & 2.9217 & 0.964 & 0.2091 \\
\hline 0.3577 & 0.8239 & 2.9701 & 0.963 & 0.2086 \\
\hline 0.3714 & 0.8553 & 3.0839 & 0.962 & 0.2076 \\
\hline 0.4094 & 0.9427 & 3.3989 & 0.958 & 0.2054 \\
\hline 0.4653 & 1.0716 & 3.8635 & 0.952 & 0.2034 \\
\hline 0.4819 & 1.1097 & 4.0009 & 0.950 & 0.2031 \\
\hline 0.4963 & 1.1430 & 4.1210 & 0.947 & 0.2030 \\
\hline 0.5138 & 1.1817 & 4.2648 & 0.946 & 0.2029 \\
\hline 0.7095 & 0.8180 & 5.0747 & 0.940 & 0.2059 \\
\hline 0.8199 & 0.4729 & 5.3923 & 0.938 & 0.2069 \\
\hline 0.8304 & 0.9530 & 5.9354 & 0.926 & 0.2108 \\
\hline 0.8480 & 0.4885 & 5.5765 & 0.933 & 0.2080 \\
\hline 0.8880 & 0.5115 & 5.8395 & 0.929 & 0.2098 \\
\hline 0.9257 & 0.5333 & 6.0875 & 0.926 & 0.2117 \\
\hline 0.9506 & 0.5476 & 6.2512 & 0.923 & 0.2131 \\
\hline 0.9917 & 0.5739 & 6.5241 & 0.919 & 0.2156 \\
\hline 1.0175 & 0.5839 & 6.6889 & 0.916 & 0.2172 \\
\hline
\end{tabular}

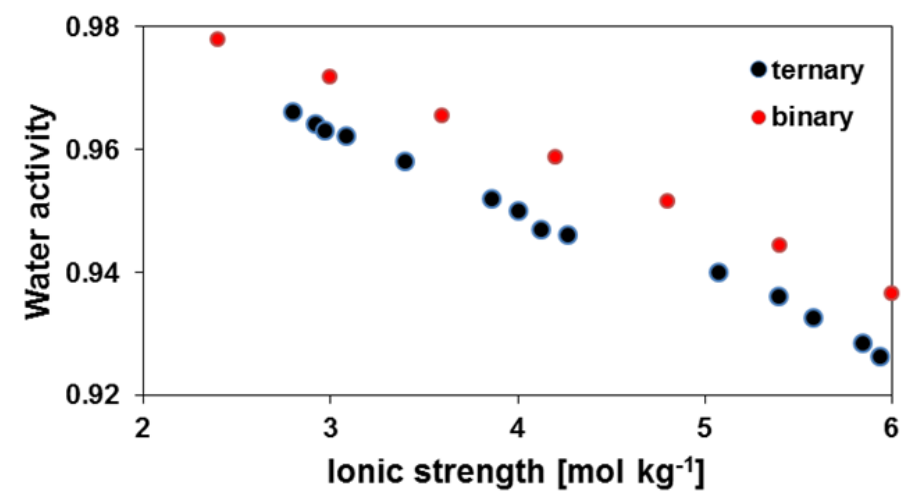

Figure 4.13. Comparison of the water activity in the $\mathrm{Eu}\left(\mathrm{NO}_{3}\right)_{3} / \underline{\mathrm{NaNO}_{3}} / \mathrm{H}_{2} \mathrm{O}$ ternary and $\mathrm{Eu}\left(\mathrm{NO}_{3}\right)_{3} / \mathrm{H}_{2} \mathrm{O}$ binary systems.

The $\mathrm{Eu}\left(\mathrm{NO}_{3}\right)_{3}$ activity coefficients for the ternary $\mathrm{Eu}\left(\mathrm{NO}_{3}\right)_{3} / \mathrm{NaNO}_{3}$ electrolyte were calculated using the $B_{E u\left(N O_{3}\right)_{3} \text { new }}=0.052$ and $B_{N_{N N O}}=-0.0128$ constants for the binary $\mathrm{Eu}\left(\mathrm{NO}_{3}\right)_{3}$ and $\mathrm{NaNO}_{3}$ electrolytes 
in equation 2 and plotted against the solution total ionic strength (Figure 4.14). The plot exhibited parabolic-like shape with the minimum near the ionic strength of $4.5 \mathrm{~mol} \mathrm{~kg}{ }^{-1}$.

Interestingly, the values of the $\mathrm{Eu}\left(\mathrm{NO}_{3}\right)_{3}$ activity coefficients for the $\mathrm{Eu}\left(\mathrm{NO}_{3}\right)_{3} / \mathrm{NaNO}_{3} / \mathrm{H}_{2} \mathrm{O}$ ternary and $\mathrm{Eu}\left(\mathrm{NO}_{3}\right)_{3} / \mathrm{H}_{2} \mathrm{O}$ binary systems system are nearly identical (Figure 4.14). This suggests that the $\mathrm{NaNO}_{3}$ electrolyte has little effect on the ion short range interactions in the ternary system.

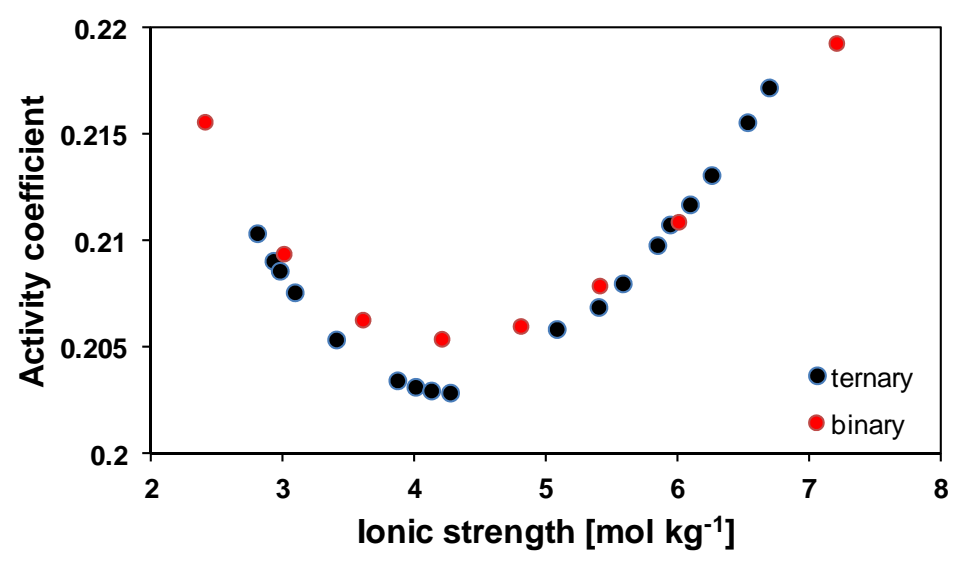

Figure 4.14. Comparison of the $\mathrm{Eu}\left(\mathrm{NO}_{3}\right)_{3}$ activity coefficients in the $\mathrm{Eu}\left(\mathrm{NO}_{3}\right)_{3} / \mathrm{NaNO}_{3} / \mathrm{H}_{2} \mathrm{O}$ ternary and $\mathrm{Eu}\left(\mathrm{NO}_{3}\right)_{3} / \mathrm{H}_{2} \mathrm{O}$ binary systems.

\section{SUMMARY}

In this study, the new Bromley parameters for the binary $\operatorname{Ln}\left(\mathrm{NO}_{3}\right)_{3}$ electrolytes were obtained based on the previous literature and our experimental data. This allows for the accurate prediction of the $\left.\mathrm{Ln}_{(\mathrm{NO}}\right)_{3}$ activity coefficients for the binary $\mathrm{Ln}\left(\mathrm{NO}_{3}\right)_{3}$ electrolytes. This model was then implemented for the determination of the $\mathrm{Ln}\left(\mathrm{NO}_{3}\right)_{3}$ activity coefficients in the ternary $\mathrm{Nd}\left(\mathrm{NO}_{3}\right)_{3} / \mathrm{HNO}_{3} / \mathrm{H}_{2} \mathrm{O}$, $\mathrm{Eu}\left(\mathrm{NO}_{3}\right)_{3} / \mathrm{HNO}_{3} / \mathrm{H}_{2} \mathrm{O}$, and $\underline{\mathrm{Eu}}\left(\mathrm{NO}_{3}\right)_{3} / \mathrm{NaNO}_{3} / \mathrm{H}_{2} \mathrm{O}$ systems.

The main achievement of this work is the verified pathway for the estimation of the activity coefficients in the multicomponent aqueous electrolyte systems. The accurate Bromley electrolytes contributions obtained in this work for the entire series of lanthanide(III) nitrates (except Pm) can be applied for predicting activity coefficients and non-ideality effects for multi-component systems containing these species. This work also provides the proof-of-principle of extending the model to more complex multicomponent systems. Moreover, this approach can also be applied to the actinide-containing electrolyte systems, for determination of the activity coefficients in concentrated radioactive solutions. 


\section{REFERENCES}

Bonal C, Morel JP, Morel-Desrosiers N. 1998. Interactions between lanthanide cations and nitrate anions in water. J. Chem. Soc., Faraday Trans. 94(10):1431-1436

Bromley, LA. 1973. Thermodynamic properties of strong electrolytes in aqueous solutions. Am. Inst. Chem. Eng. J. 19:313-320.

Charrin N, Moisy P, Garcia-Argote S, and Blanc P. 1999. Thermodynamic study of the ternary system $\mathrm{Th}\left(\mathrm{NO}_{3}\right)_{3} / \mathrm{HNO}_{3} / \mathrm{H}_{2} \mathrm{O}$. Radiochim. Acta, 86:143-149.

| Debye, P, Hückel, E, 1923. Zur Theorie der Elektrolyte. I. Gefrierpunktserniedrigung undverwandte Erscheinungen[The theory of electrolytes. I. Lowering of freezing point and related phenomena]. Physikalische Zeitschrift 24:185-206.

Hamer W and Wu YC. 1972. Osmotic Coefficients and Mean Activity Coefficients of Uni-univalent Electrolytes in Water at 25C. J. Phys. Chem. Ref. Data, 1:1047-1099.

Kanno H, Hiraishi J. 1984. Raman study of aqueous rare earth nitrate solutions in liquid and glassy states, J. Phys. Chem. 88:2787-2792.

Kappenstein AC, P Moisy, G Cote, and P Blanc. 2000. Contribution of the concept of simple solutions to calculation of the stoichiometric activity coefficients and density of ternary mixtures of hydroxylammonium or hydrazinium nitrate with nitric acid and water. Phys. Chem. Chem. Phys. 2:27252730.

Lalleman S, Bertrand M, Plasari E, Sorel C, and Moisy P. 2012. Determination of the Bromley contributions to estimate the activity coefficient of neodymium electrolytes. Chem. Eng. Sci. 77:189-195.

Levitskaia TG, Neiner D, and Robinson TA. 2011. Non-ideality in solvent extraction systems: PNNL FY 2011 Status Report, PNNL-20662, Pacific Northwest National Laboratory, Richland, WA.

Levitskaia TG, Chatterjee S, and Valerio EL. 2013. Non-ideality in solvent extraction systems: PNNL FY 2013 Status Report, PNNL-22707, Pacific Northwest National Laboratory, Richland, WA.

Marcos-Aroyo MM, Khoshkbarchi MK, Vera JH. 1996. Activity coefficients of sodium, potassium and nitrate ions in aqueous solutions of $\mathrm{NaNO}_{3}, \mathrm{KNO}_{3}$ and $\mathrm{NaNO}_{3}+\mathrm{KNO}_{3}$ at $25^{\circ} \mathrm{C}$. J. Sol. Chem. 25(10):9831000

Pitzer KS. Ion Interaction Approach: Theory and Data Correlation. in Activity Coefficients in Electrolyte Solutions. Pitzer KS, ed., CRC Press: Boca Raton, Florida, 1991; p. 75.

Rard JA, Palmer DA, and Albright JG. 2003. Isopiestic determination of the osmotic and activity coefficients of aqueous sodium trifluoromethanesulfonate at $298.15 \mathrm{~K}$ and $323.15 \mathrm{~K}$, and representation with an extended ion-interaction (Pitzer) model. J. Chem. Eng. Data, 48:158-166.

Rard JA, Shiers LE, Heiser DJ, and Spedding FH. 1977. Isopiestic determination of the activity coefficients of some aqueous rare earth electrolyte solutions at $25^{\circ} \mathrm{C}$. 3. The rare earth nitrates. J. Chem. Eng. Data 22:337-347.

Rard JA, Miller GD, and Spedding FH. 1979. Isopiestic determination of the activity-coefficients of some aqueous rare-earth electrolyte-solutions at 25C. 4. $\mathrm{La}\left(\mathrm{NO}_{3}\right)_{3}, \operatorname{Pr}\left(\mathrm{NO}_{3}\right)_{3}$, and $\mathrm{Nd}\left(\mathrm{NO}_{3}\right)_{3}$. J. Chem. Eng. Data, 24:348-354.

Rard JA, and Spedding FH. 1981. Isopiestic Determination of the Activity Coefficients of Some Aqueous Rare-Earth Electrolyte Solutions at 25C. 5. Dy $\left(\mathrm{NO}_{3}\right)_{3}, \mathrm{Ho}\left(\mathrm{NO}_{3}\right)_{3}$ and $\mathrm{Lu}\left(\mathrm{NO}_{3}\right)_{3}$. J. Chem. Eng. Data, 26:391-395 
Robinson RA, Stokes RH 1968. Electrolyte Solutions, second edition. Butterworths, London.

Ruas A, Moisy P, Simonin JP, Dufreche JF, Bernard O, Turq P. 2005a. Lanthanides salts solutions: representation of osmotic coefficients within the binding mean spherical approximation. J. Phys. Chem.B 109: $5243-5248$.

| Ruas A, Simonin, JP, Turq P, Moisy P. 2005b. Experimental_determination_of water activity for binary aqueous cerium(III)ionic solutions. Application to an assessment of the predictive capability of the BIMSA model. J. Phys. Chem. B 109, 23043-23050.

Ruas A, Guilbaud P, Den Auwer C, Moulin C, Simonin JP, Turq P, Moisy P. 2006. Experimental and molecular dynamics studies of dysprosium(III) chloride ionic solutions for a better representation of the microscopic features used within the binding mean spherical approximation theory. J.Phys.Chem.A 110,11770-11779.

Spedding FH, Weber HO, Saeger VW, Petheram HH, Rard JA, Habenschuss A. 1976. Isopiestic determination of the activity coefficients of some aqueous rare earth electrolyte solutions at $25^{\circ} \mathrm{C} . J$. Chem. Eng. Data 21, 341-360

Warin D, Poinssot C, Baron P, Lorrain B. 2009. Advanced processes for actinide partitioning: recent experiments and results. Proceedings of Global'09, Boise, Idaho, USA, pp 44-48.

Wu YC., Hamer WJ,1969. Osmotic coefficients and mean activity coefficients of a series of uniunivalent electrolytes in aqueous solutions at 25C. National Bureau of Standards Report,10002. 


\section{INDICATORS OF PROJECT QUALITY AND PRODUCTIVITY}

\subsubsection{Publications}

Levitskaia TG, TA Robinson, SA Bryan, and AJ Casella. 2010. "TALSPEAK EXTRACTION SYSTEM UNDER VARIABLE LOADING CONDITIONS_PART 1: DISTRIBUTION STUDIES." In

Proceedings of the 19th International Solvent Extraction Conference, October 3-7, 2011, Santiago, Chile, ed. F Valenzuela L. and BA Moyer, p. Paper No. 96. Society of Chemical Industry, London, United Kingdom.

Robinson TA, SA Bryan, TG Levitskaia, and D Neiner. 2011. "TALSPEAK EXTRACTION SYSTEM UNDER VARIABLE LOADING CONDITIONS_PART 2: SPECIATION STUDIES." In Proceedings of the 19th International Solvent Extraction Conference, October 3-7, 2011, Santiago, Chile, ed. F Valenzuela L. and BA Moyer, p. Paper No. 97. Society of Chemical Industry, London, United Kingdom.

\subsubsection{Presentations}

S Chatterjee, TA Robinson, EN Valerio and TG Levitskaia. 2013. "Non-ideality Effects in Aqueous Lanthanide Solutions" 37th Annual Actinide Separations Conference, Chattanooga, TN. May 2013.

Levitskaia TG, TA Robinson, and D Neiner. 2012. "Developing the methodology for determination of activity effects in aqueous electrolyte solutions." 36th Annual Actinide Separations Conference, Chattanooga, TN. May 2012. PNNL-SA-87852.

Robinson TA, and TG Levitskaia. 2012. "HDEHP Extraction Speciation under Dynamic, Moderate Loading Conditions." 67th Northwest Regional American Chemical Society Meeting, Boise, ID. June 2012. PNNL-SA-87275.

Levitskaia TG, TA Robinson, SA Bryan, and AJ Casella. 2011. "TALSPEAK Extraction System Under Variable Loading Conditions-Part 1: Distribution Studies." In ISEC 2011 XIX International Solvent Extraction Conference. PNNL-SA-77341.

Robinson TA, SA Bryan, TG Levitskaia, and D Neiner. 2011. "TALSPEAK Extraction System Under Variable Loading Conditions-Par T 2: Speciation Studies.” In ISEC 2011 XIX International Solvent Extraction Conference. PNNL-SA-77271.

Levitskaia TG, GJ Lumetta, JC Braley, D Neiner, and TA Robinson. 2011. "Modelling of Metal Ion Transport in TALSPEAK-Like Extraction Systems." In The 17th Symposium on Separation Science and Technology for Energy Applications, Gatlinburg, TN.

Robinson TA, TG Levitskaia, and AJ Casella. 2010. "TALSPEAK Organic Phase Speciation under High Loading Conditions." Presented by Troy Robinson at 2010 American Nuclear Society Winter Meeting, Las Vegas, NV on November 9, 2010. PNNL-SA-76259. 


\section{COLLABORATORS AND PARTICIPANTS}

The key researchers involved in this work are:

- Tatiana Levitskaia, Principal Investigator, responsible for overall project technical content, equilibrium modeling of solvent extraction data, and project reporting

- Natasha Pence, post-bachelor fellow

- Dev Chatterjee, investigator 